\title{
Receptor Subtypes and Signal Transduction Mechanisms Contributing to the Estrogenic Attenuation of Cannabinoid-Induced Changes in Energy Homeostasis
}

\author{
Neal Washburn ${ }^{\mathrm{a}}$ Amanda Borgquist ${ }^{\mathrm{a}}$ Kate Wang ${ }^{\mathrm{a}}$ Garrett S. Jeffery ${ }^{\mathrm{a}}$ \\ Martin J. Kelly ${ }^{\mathrm{b}}$ Edward J. Wagner ${ }^{\mathrm{a}}$ \\ ${ }^{a}$ Department of Basic Medical Sciences, Western University of Health Sciences, Pomona, Calif., and ${ }^{b}$ Department of \\ Physiology and Pharmacology, Oregon Health and Science University, Portland, Oreg., USA
}

\section{Key Words}

Estrogen - Proopiomelanocortin - Appetite •

Cannabinoids $\cdot$ Protein kinase $C \cdot$ Protein kinase A

\begin{abstract}
We examined the receptor subtypes and signal transduction mechanisms contributing to the estrogenic modulation of cannabinoid-induced changes in energy balance. Food intake and, in some cases, $\mathrm{O}_{2}$ consumption, $\mathrm{CO}_{2}$ production and the respiratory exchange ratio were evaluated in ovariectomized female guinea pigs treated s.c. with the cannabinoid receptor agonist WIN 55,212-2 or its cremephor/ethanol/0.9\% saline vehicle, and either with estradiol benzoate $(E B)$, the estrogen receptor (ER) $\alpha$ agonist PPT, the ER $\beta$ agonist DPN, the $\mathrm{G}_{\mathrm{q}}$-coupled membrane ER agonist STX, the GPR30 agonist G-1 or their respective vehicles. Patch-clamp recordings were performed in hypothalamic slices. EB, STX, PPT and G-1 decreased daily food intake. Of these, EB, STX and PPT blocked the WIN 55,212-2-induced increase in food intake within 1-4 h. The estrogenic diminution of cannabinoid-induced hyperphagia correlated with a rapid (within 15 min) attenuation of cannabinoid-mediated decreases in glutamatergic synaptic input onto arcuate neurons, which was completely blocked by inhibition of protein kinase C (PKC) and attenuated by inhibition of protein kinase A (PKA). STX,
\end{abstract}

but not PPT, mimicked this rapid estrogenic effect. However, PPT abolished the cannabinoid-induced inhibition of glutamatergic neurotransmission in cells from animals treated $24 \mathrm{~h}$ prior. The estrogenic antagonism of this presynaptic inhibition was observed in anorexigenic proopiomelanocortin neurons. These data reveal that estrogens negatively modulate cannabinoid-induced changes in energy balance via $\mathrm{G}_{\mathrm{q}}$-coupled membrane ER- and ER $\alpha$-mediated mechanisms involving activation of PKC and PKA. As such, they further our understanding of the pathways through which estrogens act to temper cannabinoid sensitivity in regulating energy homeostasis in females.

Copyright $\odot 2012$ S. Karger AG, Basel

\section{Introduction}

Estrogens exert far-reaching effects on mammalian biology - from reproduction to energy homeostasis. While many actions require gene transcription and protein synthesis to alter cell function via the activation of estrogen receptor (ER) subtypes ER $\alpha$ and $E R \beta$ (which takes hours to days), it is now well recognized that estrogenic signaling can take place on a much more rapid timescale (minutes [1]). These rapid effects usually involve the activation of membrane-delimited ERs, which

\section{KARGER}

Fax +4161306 1234

E-Mail karger@karger.com

www.karger.com
C 2012 S. Karger AG, Basel

0028-3835/13/0972-0160\$38.00/0

Accessible online at:

www.karger.com/nen
Edward J. Wagner, $\mathrm{PhD}$

Department of Basic Medical Sciences, College of Osteopathic Medicine

Western University of Health Sciences

309 E. Second Street, Pomona, CA 91766 (USA)

Tel. +1 909469 5239, E-Mail ewagner@westernu.edu 
triggers enzymatic cascades [e.g. phospholipase C (PLC)/ protein kinase $\mathrm{C}(\mathrm{PKC}) /$ phosphatidylinositol-3-kinase (PI3K)/Akt, protein kinase A (PKA)] that ultimately lead to protein phosphorylation and altered enzyme activity and ion channel function. The elucidation of these rapid events has greatly bolstered our understanding of how estrogens impact cell proliferation, learning and memory, energy balance, sexual behavior and feedback on the reproductive axis [1-4].

Recent evidence indicates that several ER receptor subtypes contribute to these rapid, membrane-delimited actions. For example, ER $\alpha$ and ER $\beta$ can associate with the plasma membrane in a caveolin-dependent fashion $[2,5]$. Membrane-initiated signaling via these receptor subtypes in neurons of the hippocampus and hypothalamic arcuate nucleus (ARC) leads to increased PKC and mitogen-activated protein kinase activity, decreased Ltype $\mathrm{Ca}^{2+}$ channel activity, as well as altered cAMP response element binding protein (CREB)-mediated phosphorylation $[2,3,6,7]$. In hypothalamic astrocytes membrane-associated $\mathrm{ER} \alpha$ activation elicits $\mathrm{Ca}^{2+}$ mobilization from intracellular stores [8], whereas in endothelial cells it stimulates the activity of nitric oxide synthase (NOS [5]). ER $\beta$ is tethered to the plasma membrane in hippocampal neurons where its activation attenuates $\mathrm{Ca}^{2+}$ channel-dependent CREB phosphorylation [2], in primary hypothalamic cultures where it mediates neuronal NOS stimulation and subsequent nitric oxide production [9], and in hypothalamic gonadotropin-releasing hormone $(\mathrm{GnRH})$ neurons where its activation rapidly increases neuronal firing by reducing $\mathrm{Ca}^{2+}$-dependent $\mathrm{K}^{+}$ currents [10]. There is also the $\mathrm{G}_{\mathrm{q}}$-coupled membrane ER (mER) that disrupts the coupling between metabotropic, $\mathrm{G}_{\mathrm{i} / \mathrm{o}}$-coupled receptors (e.g. $\mu$-opioid receptors, $\mathrm{GABA}_{B}$ receptors) from their $G$ protein-gated, inwardly rectifying $\mathrm{K}^{+}$(GIRK) channels in proopiomelanocortin (POMC) neurons [1]. These GIRK channels are localized presynaptically and postsynaptically, and allow for $\mathrm{K}^{+}$efflux that hyperpolarizes the plasma membrane - ultimately leading to reduced neuronal excitability and transmitter release $[1,11]$. In addition, there is another $G$ proteincoupled estrogen receptor, GPR30, that appears to play a role in the estrogen stimulation of prolactin secretion from the anterior pituitary [12], and in desensitizing the $5 \mathrm{HT}_{1 \mathrm{~A}}$ receptor-mediated increase in oxytocin and adrenocorticotropin secretion from the hypothalamus [13]. Finally, the plasma membrane ER, termed ER-X, is expressed in the neocortex during the neonatal period and following ischemic or neurodegenerative insult in the adult [14], but little to no evidence exists that would sug-

Estrogens, Cannabinoids and Energy

Balance gest a role for this receptor in regulating hypothalamic or homeostatic function.

It has long been known that estrogens reduce energy intake $[15,16]$ and core body temperature $[17,18]$ in both humans and rodent animal models. This would indicate an integral role of estrogens in modulating energy homeostasis. We have previously demonstrated that cannabinoids influence energy homeostasis in a sexually differentiated fashion - with male rodents being more sensitive to the appetite-modulating and temperatureregulating effects of cannabinoid CB1 receptor activation and ablation than their female counterparts [19]. This can be attributed to differential, pleiotropic actions of cannabinoids at anorexigenic ARC POMC synapses [19]. In addition, estrogens rapidly further diminish cannabinoid responsiveness in females as manifested by (1) a blockade of the hyperphagia, (2) a reduction in the magnitude and duration of the hypothermia, (3) a downregulation of hypothalamic cannabinoid CB1 receptors, and (4) a prevalent disruption of the presynaptic inhibition of excitatory glutamatergic input onto ARC POMC neurons, caused by activation of the CB1 receptor [7, 20, 21]. Given the multiplicity of ER subtypes that conceivably could alter cell function in a rapid timescale, we wanted to determine those which contribute to the powerful estrogenic impediment to these cannabinoid-induced changes in energy balance. In addition, we endeavored to elucidate the signal transduction pathways responsible, at least in part, for uncoupling the $\mathrm{CB} 1$ receptor from effector systems that ultimately serve to decrease glutamatergic transmission at ARC POMC synapses. To this end, the non-selective endogenous steroid $17 \beta$-estradiol $\left(\mathrm{E}_{2}\right)$, the $\mathrm{ER} \alpha$-selective agonist PPT, the ER $\beta$-selective agonist DPN, the $\mathrm{G}_{\mathrm{q}}$-coupled $\mathrm{mER}$ agonist STX and the GPR30 agonist G-1 were evaluated for their ability to attenuate basal and/or cannabinoid receptor agonist-induced increases in cumulative and daily food intake. We also examined whether these estrogenic agents could curtail cannabinoid-induced decreases in glutamatergic synaptic input onto ARC POMC neurons, and whether this could be attributed to estrogenic modulation of the expression and activity of PKA and PKC.

\section{Materials and Methods}

Animals

All animal procedures described in this study have been approved by the Institutional Animal Care and Use Committee at Western University of Health Sciences. Female Topeka guinea pigs (350-600 g; 36-94 days of age) were obtained from Elm Hill 
Table 1. Information table for the compounds utilized in the present study

\begin{tabular}{|c|c|c|c|c|c|}
\hline Drug & $\begin{array}{l}\text { Abbre- } \\
\text { viation }\end{array}$ & Purpose & Vehicle & $\begin{array}{l}\text { Dose } \\
\text { (in vivo } \\
\text { studies) }\end{array}$ & $\begin{array}{l}\text { Concentra- } \\
\text { tion (in vitro } \\
\text { studies) }\end{array}$ \\
\hline Estradiol benzoate & $\mathrm{EB}$ & $\begin{array}{l}\text { modified } \\
\text { endogenous } \\
\text { steroid }\end{array}$ & sesame oil & $\begin{array}{l}10 \mu g \\
\text { s.c. }\end{array}$ & $\mathrm{N} / \mathrm{A}$ \\
\hline $4,4^{\prime}, 4^{\prime \prime}$-(4-propyl-[1H]-pyrazole-1,3,5-triyl)trisphenol & PPT & $\mathrm{ER} \alpha$ agonist & $\begin{array}{l}\text { sesame oil (in vivo)/ } \\
\text { punctilious ethanol (in vitro) }\end{array}$ & $\begin{array}{l}200 \mu g \\
\text { s.c. }\end{array}$ & $1 \mu \mathrm{M}$ \\
\hline 2,3-bis(4-hydroxyphenyl)-propionitrile & $\mathrm{DPN}$ & ER $\beta$ agonist & sesame oil & $\begin{array}{l}500 \mu g \\
\text { s.c. }\end{array}$ & $\mathrm{N} / \mathrm{A}$ \\
\hline $\begin{array}{l}\mathrm{X} \text { isomer of the non-steroidal diphenylacrylamide made by } \\
\text { Sandra Tobias }\end{array}$ & STX & $\begin{array}{l}\mathrm{G}_{\mathrm{q}} \text {-coupled mER } \\
\text { agonist }\end{array}$ & $\begin{array}{l}\text { propylene glycol (in vivo)/ } \\
\text { DMSO (in vitro) }\end{array}$ & $\begin{array}{l}3 \mathrm{mg} \\
\text { s.c. }\end{array}$ & $10 \mathrm{nM}$ \\
\hline $\begin{array}{l}( \pm)-1-\left[\left(3 \mathrm{a} R^{*}, 4 S^{*}, 9 \mathrm{~b} S^{*}\right)-4 \text {-(6-bromo-1,3-benzodioxol-5-yl)- }\right. \\
\text { 3a,4,5,9b-tetrahydro-3H-cyclopenta[c]quinolin-8-yl]- } \\
\text { ethanone }\end{array}$ & G-1 & $\begin{array}{l}\text { GPR30 receptor } \\
\text { agonist }\end{array}$ & DMSO & $\begin{array}{l}400 \mu g \\
\text { s.c. }\end{array}$ & $3 \mu \mathrm{M}$ \\
\hline $\begin{array}{l}(\mathrm{R})-(+)-[2,3 \text {-dihydro-5-methyl-3-(4-morpholinylmethyl) } \\
\text { pyrrolo[1,2,3-de]-1,4-benzoxazin-6-yl]-1- } \\
\text { naphthalenylmethanone }\end{array}$ & $\begin{array}{l}\text { WIN } \\
55,212-2\end{array}$ & $\begin{array}{l}\text { cannabinoid } \\
\mathrm{CB}_{1} / \mathrm{CB}_{2} \\
\text { receptor agonist }\end{array}$ & $\begin{array}{l}\text { cremephor/ethanol/ } \\
\text { saline (in vivo)/DMSO } \\
\text { (in vitro) }\end{array}$ & $\begin{array}{l}0.1 \mathrm{mg} / \mathrm{kg} \\
\text { s.c. }\end{array}$ & $0.03-10 \mu \mathrm{M}$ \\
\hline $\begin{array}{l}N \text {-(piperidin-1-yl)-5-(4-iodophenyl)-1-(2,4-dichlorophenyl)- } \\
\text { 4-methyl-1H-pyrazole-3-carboxamide }\end{array}$ & AM251 & $\begin{array}{l}\text { CB1 receptor } \\
\text { antagonist }\end{array}$ & cremephor/ethanol/saline & $\begin{array}{l}3 \mathrm{mg} / \mathrm{kg} \\
\text { s.c. }\end{array}$ & $\mathrm{N} / \mathrm{A}$ \\
\hline $17 \beta$-estradiol & $\mathrm{E}_{2}$ & $\begin{array}{l}\text { endogenous ER } \\
\text { agonist }\end{array}$ & punctilious ethanol & $\mathrm{N} / \mathrm{A}$ & $100 \mathrm{nM}$ \\
\hline $17 \alpha$-estradiol & $\mathrm{N} / \mathrm{A}$ & $\begin{array}{l}\text { inactive } \\
\text { enantiomer }\end{array}$ & punctilious ethanol & $\mathrm{N} / \mathrm{A}$ & $100 \mathrm{nM}$ \\
\hline $\begin{array}{l}\text { (2S)-2,6-diamino-N-[[1-(1-oxotridecyl)-2-piperidinyl] } \\
\text { methyl]hexanamide dihydrochloride }\end{array}$ & $\begin{array}{l}\text { NPC } \\
15437\end{array}$ & PKC inhibitor & DMSO & $\mathrm{N} / \mathrm{A}$ & $30 \mu \mathrm{M}$ \\
\hline $\begin{array}{l}(9 R, 10 S, 12 S) \text {-2,3,9,10,11,12-hexahydro-10-hydroxy-9-methyl- } \\
\text { 1-oxo-9,12-epoxy-1H-diindolo }\left[1,2,3-f g: 3^{\prime}, 2^{\prime}, 1^{\prime}-k l\right] \text { pyrrolo } \\
{[3,4-i][1,6] \text { benzodiazocine-10-carboxylic acid, hexyl ester }}\end{array}$ & KT 5720 & PKA inhibitor & DMSO & $\mathrm{N} / \mathrm{A}$ & $300 \mathrm{nM}$ \\
\hline
\end{tabular}

Breeding Labs (Chelmsford, Mass., USA) or bred in our animal care facility, kept under controlled temperature $\left(21-23^{\circ} \mathrm{C}\right)$ and light (12 h on, $12 \mathrm{~h}$ off), and provided with food and water ad libitum. They were ovariectomized under ketamine/xylazine anesthesia (33 and $6 \mathrm{mg} / \mathrm{kg}$, respectively; s.c.) supplemented with $2 \%$ isoflurane $4-8$ days prior to experimentation.

Drugs

Unless otherwise indicated, all drugs were obtained from Tocris Cookson, Inc. (Ellisville, Mo., USA). For the feeding, molecular biological and electrophysiological studies that involved the systemic administration of drugs, estradiol benzoate (EB; Steraloids, Newport, R.I., USA), 4,4',4"'-(4-propyl-[1H]-pyrazole1,3,5-triyl)trisphenol (PPT) and 2,3-bis(4-hydroxyphenyl)-propionitrile (DPN) were initially prepared as $1 \mathrm{mg} / \mathrm{ml}$ stock solutions in punctilious ethanol. Known quantities of these stock solutions were added to a volume of sesame oil sufficient to produce final concentrations of $100 \mu \mathrm{g} / \mathrm{ml}$ of EB, $2 \mathrm{mg} / \mathrm{ml}$ of PPT and $5 \mathrm{mg} / \mathrm{ml}$ of DPN, following evaporation of the ethanol. ( \pm )-1-[(3a $\left.R^{*}, 4 S^{*}, 9 \mathrm{~b} S^{*}\right)$-4-(6-bromo-1,3-benzodioxol-5-yl)3a,4,5,9b-tetrahydro-3H-cyclopenta[c]quinolin-8-yl]-ethanone
(G-1) was dissolved in dimethyl sulfoxide (DMSO) to a stock concentration of $4 \mathrm{mg} / \mathrm{ml}$. The non-steroidal diphenylacrylamide STX was dissolved in propylene glycol to a stock concentration of $30 \mathrm{mg} / \mathrm{ml}$. $N$-(piperidin-1-yl)-5-(4-iodophenyl)-1-(2,4dichlorophenyl)-4-methyl-1H-pyrazole-3-carboxamide (AM251) and (R)-(+)-[2,3-dihydro-5-methyl-3-(4-morpholinylmethyl) pyrrolo[1,2,3-de]-1,4-benzoxazin-6-yl]-1-naphthalenylmethanone mesylate (WIN 55,212-2) were dissolved in cremephor/ethanol/0.9\% saline (1/1/18; v/v/v). For the electrophysiological experiments involving the perfusion of drugs in hypothalamic slices, tetrodotoxin (TTX) with citrate (Alomone Labs, Jerusalem, Israel) and 6-imino-3-(4-methoxyphenyl)-1(6H)-pyridazinebutanoic acid hydrobromide (SR 95531) were dissolved in ultrapure $\mathrm{H}_{2} \mathrm{O}$ to stock concentrations of 1 and $10 \mathrm{mM}$, respectively. $\mathrm{E}_{2}$ (Steraloids), $17 \alpha$-estradiol (Steraloids) and PPT were dissolved in punctilious ethanol to stock concentrations of 1,1 and $10 \mathrm{mM}$, respectively. WIN 55,212-2, STX, G-1, (2S)-2,6-diamino-N-[[1-(1-oxotridecyl)2-piperidinyl]methyl]hexanamide dihydrochloride (NPC 15437) and $(9 R, 10 S, 12 S)-2,3,9,10,11,12$-hexahydro-10-hydroxy-9-methyl-1-oxo-9,12-epoxy-1H-diindolo[1,2,3-fg: $\left.3^{\prime}, 2^{\prime}, 1^{\prime}-k l\right]$ pyrrolo[3,4i] $[1,6]$ benzodiazocine-10-carboxylic acid, hexyl ester (KT 5720) 


\section{TIMELINE OF FEEDING STUDY EXPERIMENTS}

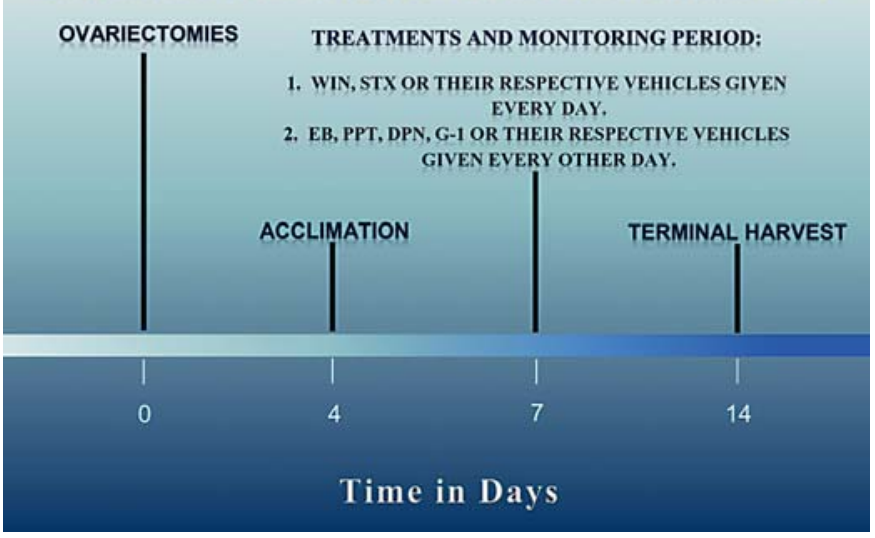

Fig. 1. A time line that illustrates the protocol for the feeding/ metabolic studies.

were dissolved in DMSO to stock concentrations of $10 \mathrm{mM}, 1 \mathrm{mM}$, $3 \mathrm{mM}, 30 \mathrm{mM}$ and $300 \mu \mathrm{M}$, respectively. This information is summarized in table 1.

\section{Feeding and Metabolic Studies}

The feeding studies were performed using a Comprehensive Lab Animal Monitoring System (CLAMS; Columbus Instruments, Columbus, Ohio, USA) as previously described [20]. Briefly, food intake was monitored around the clock for 7 days in females ovariectomized 4 days prior to acclimation to the CLAMS chambers, and 7 days prior to the start of the monitoring (fig. 1). Our CLAMS also was upgraded recently to measure $\mathrm{O}_{2}$ consumption, $\mathrm{CO}_{2}$ production and the respiratory exchange ratio, and therefore equipped to monitor energy expenditure. Each morning at 8:00 a.m. the animals were injected with either the mixed cannabinoid $\mathrm{CB}_{1} / \mathrm{CB}_{2}$ receptor agonist WIN 55,212-2 (0.1 $\mathrm{mg} / \mathrm{kg}$; s.c.) or its cremephor/ethanol saline (1/1/18; v/v/v) vehicle (1 ml/kg; s.c.). Every other morning they were also injected either with EB (10 $\mu$ g; s.c.), PPT (200 $\mu$ g; s.c.) G-1 (400 $\mu$ g; s.c.), DPN $(500 \mu \mathrm{g}$; s.c.), or their sesame oil (EB, PPT, DPN) or DMSO (G-1) vehicle $(0.1 \mathrm{ml}$; s.c.). In experiments involving STX, animals were injected s.c. daily with either a dose of $3 \mathrm{mg}$ or its propylene glycol vehicle $(0.1 \mathrm{ml})$ as described previously [18]. All of the doses of the estrogenic and cannabinoid ligands used in these in vivo studies were ascertained after careful consideration of the literature, or derived from our previously published work $[18,20,22$, 23]. A time line for the execution of these studies is provided in figure 1.

\section{Quantitative PCR}

To determine the effect of $\mathrm{CB} 1$ receptor antagonism on the expression of the PKC $\delta$ isoform and the PKA type I regulatory subunit $\alpha$ (PKA RI $\alpha$ ) in the ARC, some animals were treated for 7 days with either AM251 (3 mg/kg; s.c.) or its cremephor/ethanol $/ 0.9 \%$ saline vehicle. At the end of the 7 days, the animals were decapitated and the brain rapidly removed. Three coronal slices
(1 $\mathrm{mm}$ in thickness) spanning the rostral-caudal extent of the ARC were prepared using a guinea pig brain matrix (Ted Pella, Inc., Redding, Calif., USA), and stored in RNAlater (Ambion, Inc., Austin, Tex., USA) for $2-3 \mathrm{~h}$. The ARC was then microdissected from 2 to 3 of these slices according to the guinea pig brain atlas generated by Tindal [24].

The primer sequences for PKC $\delta$ and PKA RI $\alpha$ were synthesized by and purchased from Invitrogen (Carlsbad, Calif., USA). They were chosen by analyzing sequences originally designed, characterized and used elsewhere $[25,26]$ that, in our hands, met the efficiency and melting point dissociation criteria described below.

Total RNA from each sample was extracted using the RNAqueous-Micro Kit (Ambion, Inc.) as per the manufacturer's specifications. It was then quantified with a NanoVue spectrophotometer (GE Healthcare Life Sciences, Piscataway, N.J., USA), and treated with DNase I (DNA free, Ambion; $37^{\circ} \mathrm{C}$ for $30 \mathrm{~min}$ ) to minimize contamination by genomic DNA. SuperScript ${ }^{\mathrm{TM}}$ III reverse transcriptase (200 U; Invitrogen), along with $3 \mu \mathrm{l} 5 \times$ buffer, $15 \mathrm{mM}$ $\mathrm{MgCl}_{2}, 10 \mathrm{mM}$ dNTP, $100 \mathrm{ng}$ random hexamer primers, $40 \mathrm{U} / \mu \mathrm{l}$ RNaseOUT $^{\mathrm{TM}}$ and $100 \mathrm{mM}$ dithiothreitol (in diethylpyrocarbonate water) were used to generate cDNA from 200 ng RNA (20 $\mu \mathrm{l}$ total reaction volume). Reverse transcription was carried out as follows: $5 \mathrm{~min}$ at $25^{\circ} \mathrm{C}, 60 \mathrm{~min}$ at $50^{\circ} \mathrm{C}, 15 \mathrm{~min}$ at $70^{\circ} \mathrm{C}$ and $5 \mathrm{~min}$ at $4^{\circ} \mathrm{C}$. The resultant $\mathrm{CDNA}$ was then diluted $20 \times$ with nucleasefree water (Ambion Inc.) and stored at $-20^{\circ} \mathrm{C}$.

For quantitative PCR, cDNA $(3-4 \mu \mathrm{l})$ was amplified with a Power SYBR ${ }^{\circledR}$ Green master mix (Applied Biosystems, Carlsbad, Calif., USA) using an ABI 7300 Fast Real-time PCR machine. Standard curves for each pair of primers were generated using serial dilutions of mediobasal hypothalamic or hippocampal cDNA in triplicate to calculate their efficiency (E) via the following relationship: $\mathrm{E}=10\left(^{-1 / \mathrm{m}}\right)-1$, where $\mathrm{m}$ equals the slope of the standard curve. All of the primer efficiencies were $>90 \%$. The amplification of cDNA started with an initial denaturation at $95^{\circ} \mathrm{C}$ for 10 min, followed by 45 cycles of amplification at $94^{\circ} \mathrm{C}$ for $15 \mathrm{~s}$ (denaturing) and at $60^{\circ} \mathrm{C}$ for $30 \mathrm{~s}$ (annealing), and completed with a dissociation step for melting point analysis consisting of 35 cycles of $95^{\circ} \mathrm{C}$ for $15 \mathrm{~s}, 60-95^{\circ} \mathrm{C}$ at $1^{\circ} \mathrm{C}$ increments over $1 \mathrm{~min}$ and $95^{\circ} \mathrm{C}$ for $15 \mathrm{~s}$. All amplification runs included the appropriate positive and negative controls as used by others, and relative quantification was performed using the comparative CT method as described in detail elsewhere [27-29].

\section{Electrophysiology}

Electrophysiological recordings of ARC neurons were performed in hypothalamic slices prepared from female guinea pigs ovariectomized 6-8 days prior to experimentation as previously described [7]. Briefly, electrode resistances varied from 3-8 M $\Omega$. Membrane currents were recorded in voltage clamp with access resistances ranging from 8-20 M $\Omega$, and underwent analog-digital conversion via a Digidata $1322 \mathrm{~A}$ interface coupled to pClamp 8.2 software (Axon Instruments). The access resistance, as well as the resting membrane potential and the input resistance, were monitored throughout the course of the recording. If the access resistance deviated $>20 \%$ of its original value, the recording was ended. To ascertain the ER subtypes that contribute to the rapid attenuation of the cannabinoid receptor agonist-induced decreases in glutamatergic mEPSCs, cells were perfused in artificial cerebrospinal fluid in the presence of $500 \mathrm{nM}$ TTX and $10 \mu \mathrm{M}$ SR 


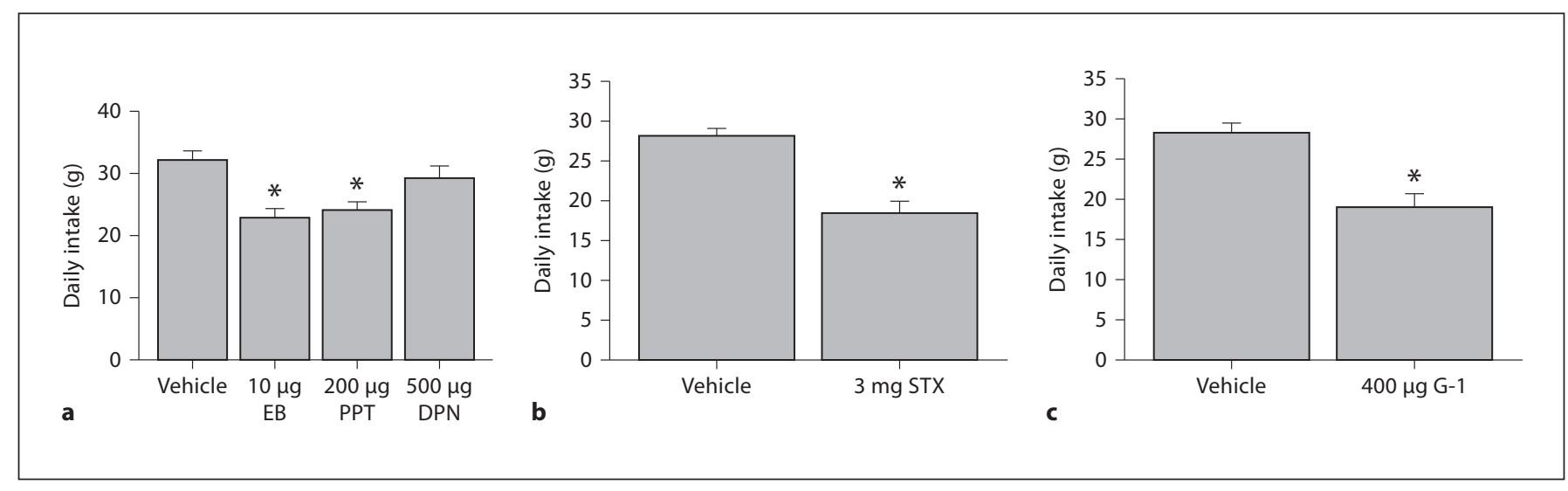

Fig. 2. $\mathrm{EB}(\mathbf{a}), \operatorname{PPT}(\mathbf{a}), \operatorname{STX}(\mathbf{b})$ and G-1 (c), but not DPN (a), decrease daily food intake. Bars represent means and vertical lines 1 SEM of the daily intake elicited in animals treated with either EB (10 $\mu$ g; s.c.), PPT (200 $\mu$ g; s.c.), STX (3 mg; s.c.), G-1 (400 $\mu$ g; s.c.), DPN (500 $\mu$ g ; s.c.) or their respective sesame oil (a), propyl- ene glycol (b) or DMSO (c) vehicles $(0.1 \mathrm{ml}) .{ }^{*}$ Values that are significantly different [one-way ANOVA/LSD: $\mathrm{p}<0.05$ (a); Student's t test: $\mathrm{p}<0.05$ (b and $\mathbf{c}$ )] than those from vehicle-treated controls $(\mathrm{n}=4-7)$.
95531 to block $\mathrm{GABA}_{\mathrm{A}}$ receptor-mediated synaptic input, and also with $100 \mathrm{nM} \mathrm{E}_{2}, 100 \mathrm{nM} 17 \alpha$-estradiol, $10 \mathrm{nM} \mathrm{STX,} 3 \mu \mathrm{M} \mathrm{G}-1$, $1 \mu \mathrm{M}$ PPT, or their respective vehicle solutions $(0.001-0.01 \%$ by volume), alone or in combination with the PKC inhibitor NPC $15437(30 \mu \mathrm{M})$ or the PKA inhibitor KT 5720 (300 nM) for 10-15 $\mathrm{min}$. Baseline recordings were performed from a holding potential of $-75 \mathrm{mV}$ for 3-4 min. Both ER ligand-treated and vehicletreated slices were then perfused with varying concentrations of the cannabinoid receptor agonist WIN 55,212-2 (30 nM to $10 \mu \mathrm{M})$, and 3-4 more minutes of data were collected. Measurements were obtained from at least 100 contiguous mEPSCs, and were analyzed to determine alterations in frequency and amplitude prior to, and in the presence of, these compounds. All of the concentrations of the estrogenic and cannabinoid ligands, as well as the kinase inhibitors, used in these in vitro studies were determined after careful consultation of the literature, or derived from our previously published work [20,30-36]. After recording from cells that exhibited characteristics of POMC neurons such as the hyperpolarization-activated cation current, the A-type $\mathrm{K}^{+}$current and estrogenic modulation of cannabinoid signaling [20], some of these slices were processed for immunohistofluorescence using phenotypic markers of POMC neurons as described previously [20].

\section{Statistics}

Comparisons between two groups were made with either the Student t test or the Mann-Whitney U test. Comparisons between more than two groups were performed using the one-way or multifactorial analysis of variance (ANOVA) followed by the least significant difference (LSD) test, or alternatively via the KruskalWallis test followed by analysis of the median-notched box and whisker plot. Comparisons of the mEPSC interval distributions observed under basal and cannabinoid receptor agonist-treated conditions were evaluated via the Kolmogorov-Smirnov test. Differences were considered statistically significant if the probability of error was $<5 \%$.

\section{Results}

Experiment 1: Estrogenic and Cannabinoid Effects on Food Intake and Energy Expenditure

We first set out to determine the receptor subtypes responsible for the estrogenic attenuation of food intake in ovariectomized female guinea pigs. As shown in figure 2,

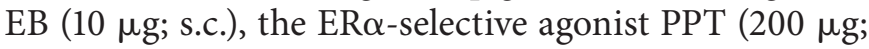
s.c.), the $\mathrm{G}_{\mathrm{q}}$-coupled $\mathrm{mER}$ ligand STX (3 mg; s.c.), and the GPR30-selective agonist G-1 (400 $\mu$ g; s.c.) all reduced total 24-hour intake. The ER $\beta$-selective agonist DPN (500 $\mu g$; s.c.) was without effect. On the other hand, the cannabinoid receptor agonist WIN 55,212-2 (0.1 mg/kg; s.c.) stimulated food intake (fig. 3a). This hyperphagic response is associated with time-dependent decreases in $\mathrm{O}_{2}$ consumption (fig. $3 \mathrm{~b}$ ) and $\mathrm{CO}_{2}$ production (fig. 3c), with no effect on the respiratory exchange ratio (fig. $3 \mathrm{~d}$ ), and is consistent with what we have demonstrated previously $[19,20]$.

\section{Experiment 2: The Rapid Modulatory Effects of ER} Activation on Cannabinoid-Induced Hyperphagia

EB abolishes cannabinoid-induced hyperphagia and hypothermia [20]. As such, we wanted to see whether STX, PPT and/or G-1 could similarly attenuate the increases in appetite produced by WIN 55,212-2. As shown in figure $4 \mathrm{a}, \mathrm{EB}$ produced its rapid and complete antagonism of the cannabinoid-induced increase in cumulative intake that was observed no later than $1 \mathrm{~h}$ after injection. STX per se decreased food intake $4 \mathrm{~h}$ after its 
Fig. 3. WIN 55,212-2 increases food intake (a) concomitant with decreases in $\mathrm{O}_{2}$ consumption (b), $\mathrm{CO}_{2}$ production (c) and no effect on the respiratory exchange ratio (d). Bars represent means and vertical lines 1 SEM of the cumulative intake, as well as incremental $\mathrm{O}_{2}$ consumption, $\mathrm{CO}_{2}$ production and the respiratory exchange ratio seen in animals treated with either WIN 55,212-2 (0.1 mg/kg; s.c.) or its vehicle $(0.1 \mathrm{ml} / \mathrm{kg}$; s.c.). * Values that are significantly different (multifactorial ANOVA/LSD; $\mathrm{p}<0.05$ ) than those from vehicle-treated controls $(n=4-7)$.
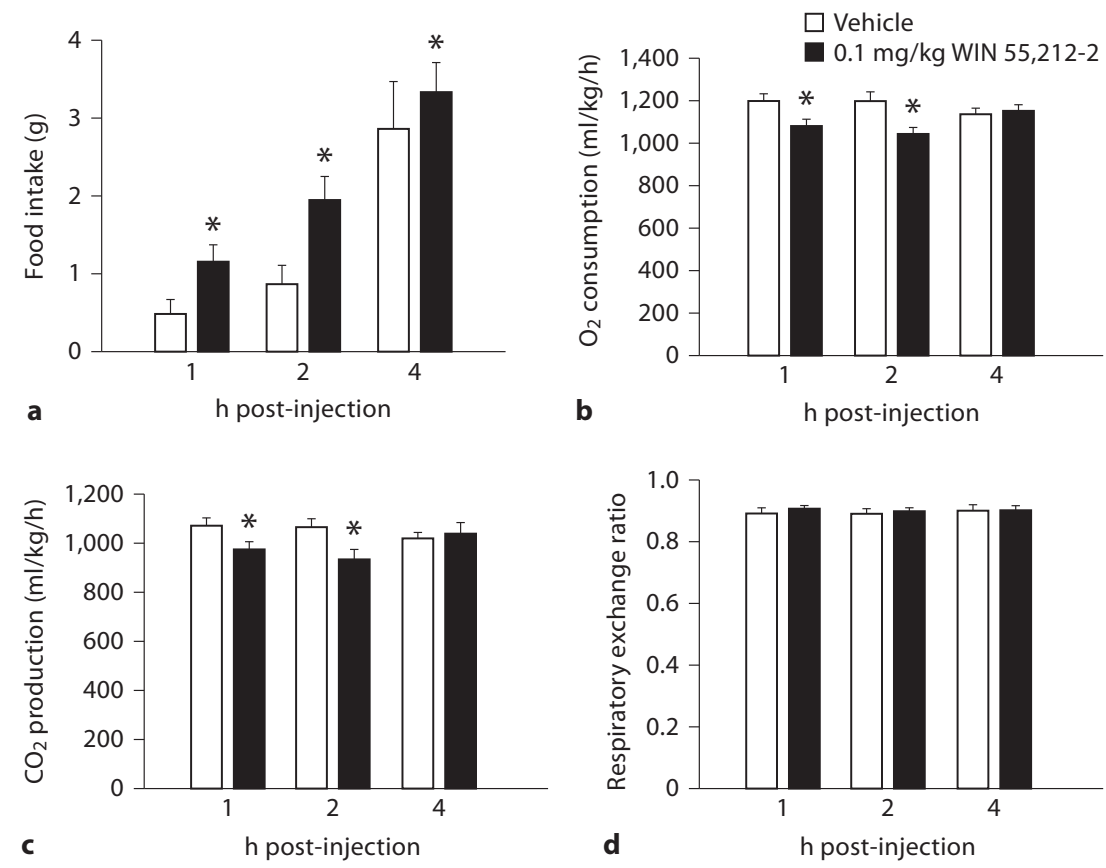

administration and, like EB, rapidly (within $1 \mathrm{~h}$ ) and completely blocked the cannabinoid agonist-induced increase in food intake (fig. 4b). On the other hand, PPT also blocked the cannabinoid-induced increase in consumption, but this was not apparent until $4 \mathrm{~h}$ following injection (fig. 4c). By contrast, G-1 was ineffectual against the hyperphagia produced by WIN 55,212-2 (fig. 4d).

Experiment 3: The Role of PKC and PKA in the Rapid Estrogenic Modulation of Cannabinoid-Induced

Decreases in Glutamatergic Neurotransmission at POMC Synapses

We have previously shown that estrogens dramatically attenuate the CB1 receptor agonist-induced presynaptic inhibition of glutamatergic transmission at ARC POMC synapses in a rapid and sustained fashion via an ER-mediated mechanism [7,34]. This is manifest by a marked, $\mathrm{E}_{2}$-induced diminution of the dose-dependent decrease in mEPSC frequency produced by WIN 55,212-2 (fig. 5a-d). Of the 26 cells (out of 139 in total) tested in the present study based on the criteria described in the Electrophysiology section of the Materials and Methods, 20 were immunopositive for $\alpha$-melano-

Estrogens, Cannabinoids and Energy

Balance cyte-stimulating hormone ( $\alpha$-MSH), cocaine- and amphetamine-regulated transcript (CART), or $\beta$-endorphin. The estrogenic effect is stereoselective in that transient (10-15 $\mathrm{min})$ exposure of the hypothalamic slices to $17 \alpha$-estradiol $(100 \mathrm{nM})$ failed to replicate the impairment of the cannabinoid-induced decrease in mEPSC frequency produced by an equivalent exposure and concentration of $\mathrm{E}_{2}$ (fig. 6). Given that estrogens uncouple metabotropic, $\mathrm{G}_{\mathrm{i} / \mathrm{o}}$-coupled receptors from GIRK channels in POMC neurons via a PLC/PKC/PKA pathway [1], we decided to test whether inhibition of PKC or PKA also could prevent the $\mathrm{E}_{2}$-induced impediment to the presynaptic inhibition of glutamatergic neurotransmission produced by cannabinoid receptor activation. As shown in figure 7, the PKC inhibitor NPC 15437 (30 $\mu \mathrm{M})$ completely restored the ability of WIN $55,212-2$ to decrease $\mathrm{mEPSC}$ frequency at POMC synapses, whereas the PKA inhibitor KT 5720 (300 nM) at least partially overcame the negative modulatory effects of $\mathrm{E}_{2}$ in this regard. This is consistent with the increase in PKC $\delta$ expression and the modest, albeit statistically insignificant, elevation in PKA R1 $\alpha$ expression seen in the ARC following treatment with the $\mathrm{CB} 1$ receptor antagonist AM251 (3 mg/kg; fig. 8). 


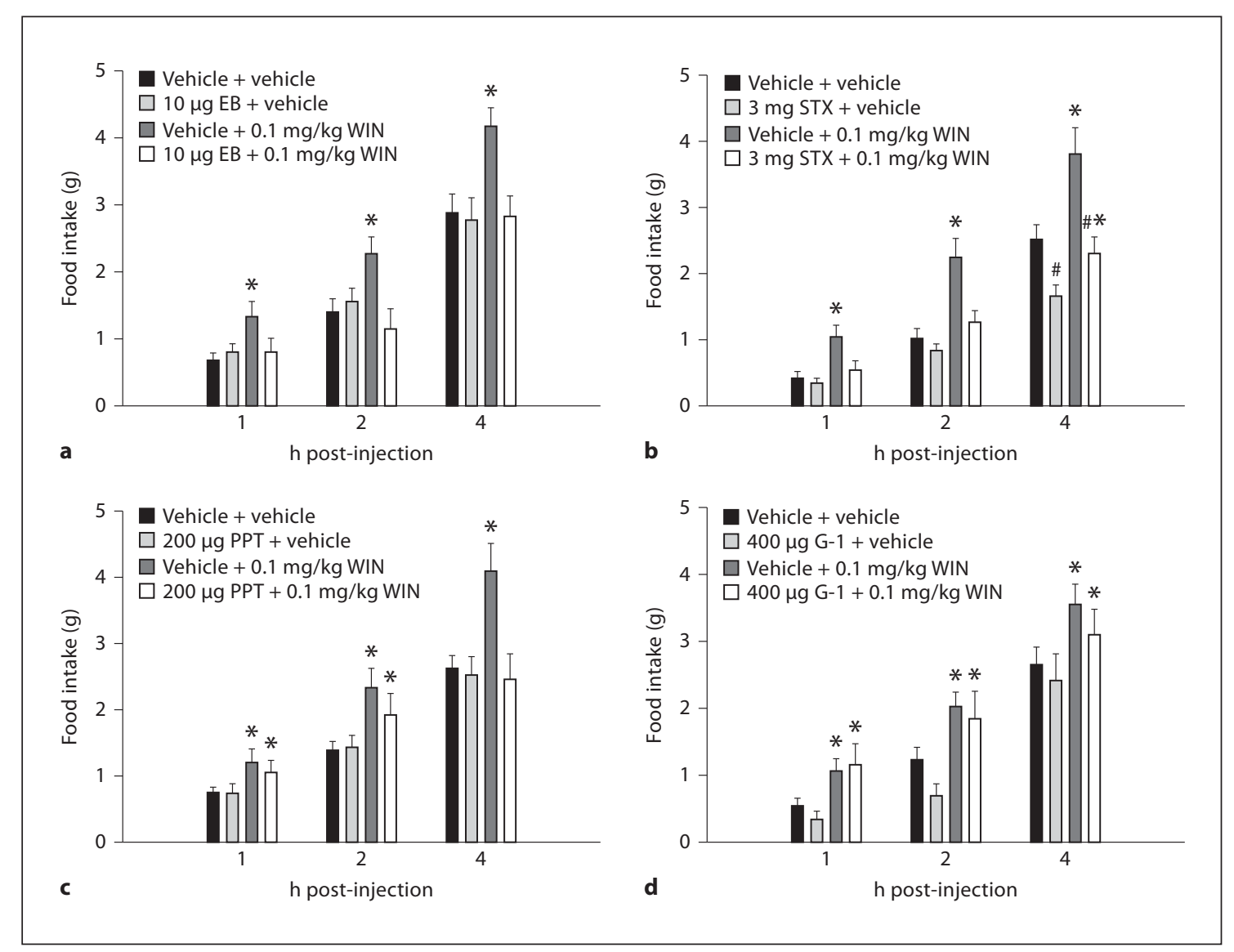

Fig. 4. EB (a), STX (b) and PPT (c), but not G-1 (d), negatively modulate cannabinoid-induced changes in food intake. Bars represent means and vertical lines 1 SEM of the food intake measured at 1, 2 and $4 \mathrm{~h}$ for 7 days. In $\mathbf{b}$, animals were treated daily (8:00 a.m.) with STX (3 mg; s.c.) or its propylene glycol vehicle (0.1 $\mathrm{ml}$; s.c.), and/or with WIN 55,212-2 (0.1 mg/kg; s.c.) or its cremephor/ethanol/saline vehicle. In $\mathbf{a}, \mathbf{c}$, and $\mathbf{d}$, animals were subject to the same dosing regimen as described above for WIN 55,212-2 and its vehicle, and treated every other day with EB (10 $\mu$ g; s.c.),

Experiment 4: The Role of the $G_{q}$-Coupled $m E R, E R \alpha$ and GPR30 in the Rapid Estrogenic Modulation of Cannabinoid-Induced Decreases in Glutamatergic Neurotransmission at POMC Synapses

To determine the receptor subtypes responsible for the ER-mediated disruption of cannabinoid-induced decrements in glutamatergic neurotransmission, we evaluated the effects of WIN 55,212-2 on mEPSC frequency in slices treated with STX (10 nM), PPT (1 $\mu \mathrm{M})$, G-1 $(3 \mu \mathrm{M})$ or their respective vehicle solutions. Like $\mathrm{E}_{2}$, the transient application of STX markedly diminished the decrease in mEPSC frequency caused by WIN 55,212-2 (fig. 9, 10c). However, similar treatment with PPT was without effect
PPT (200 $\mu$ g; s.c.), G-1 (400 $\mu$ g; s.c.) or their respective vehicle solutions $\left(0.1 \mathrm{ml}\right.$; s.c.). ${ }^{*}$ Values of food intake measured in animals treated with WIN 55,212-2 that are significantly different (multifactorial ANOVA/LSD; $\mathrm{p}<0.05 ; \mathrm{n}=4-7$ ) than those measured in vehicle-treated controls. "Values from STX-, PPT-, EB- or G-1-treated animals that are significantly different (multi-factorial ANOVA/LSD; $\mathrm{p}<0.05 ; \mathrm{n}=4-7$ ) than those from their vehicle-treated counterparts.

(fig. 10). In addition, G-1 was unable to prevent the reduction in MEPSC frequency (fig. 10), which is in keeping with its lack of effect on the cannabinoid-evoked hyperphagia.

\section{Experiment 5: The Role of ER $\alpha$ in Sustaining \\ Estrogenic Modulation of Cannabinoid-Induced \\ Decreases in Glutamatergic Neurotransmission at \\ POMC Synapses}

While the brief application of $\mathrm{E}_{2}$ can clearly abrogate the cannabinoid-induced presynaptic inhibition of glutamatergic input onto POMC neurons, this effect is quite long-lasting as evidenced by the fact that EB administered 


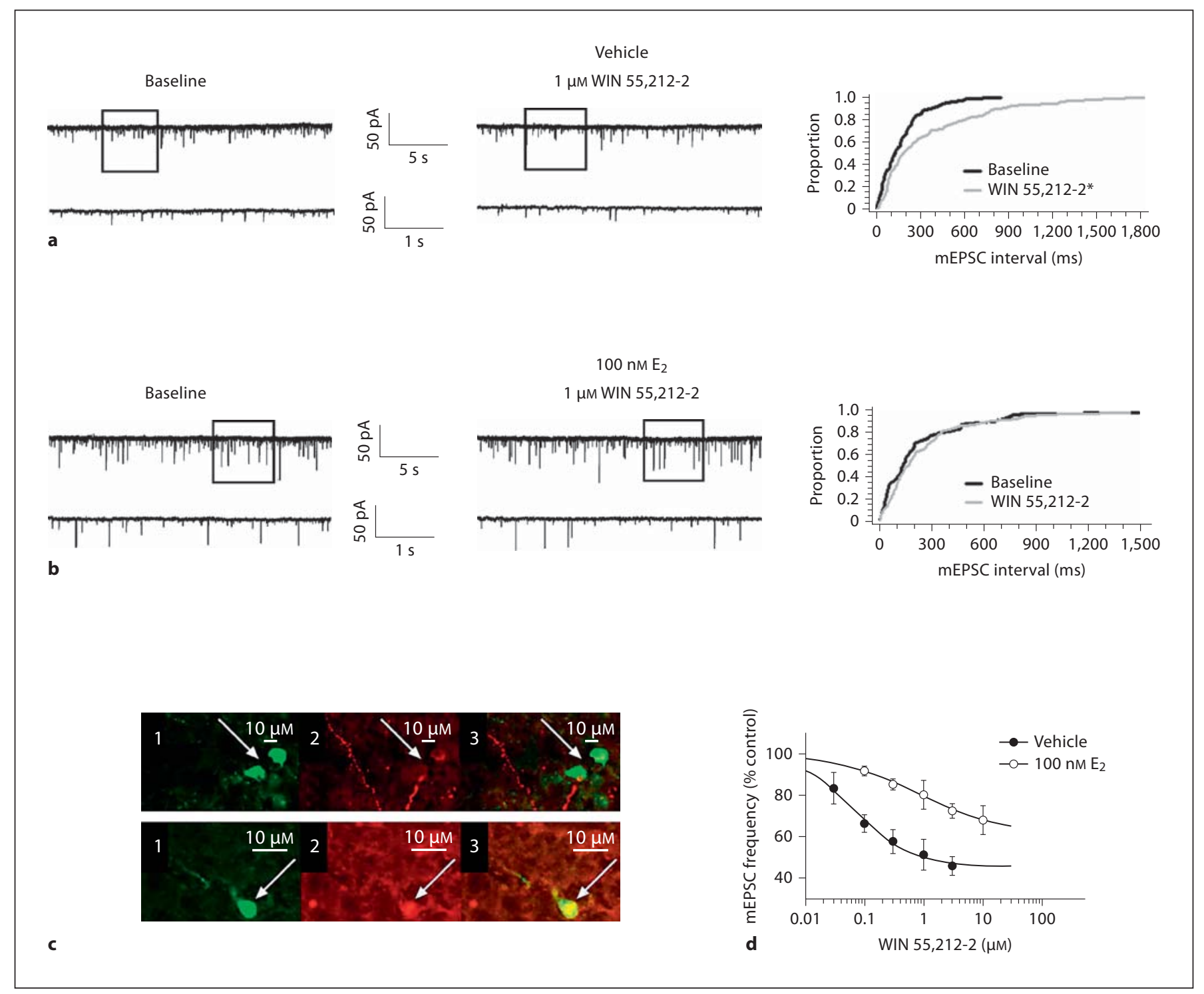

Fig. 5. $\mathrm{E}_{2}$ rapidly attenuates the cannabinoid-induced presynaptic inhibition of glutamatergic synaptic input onto ARC POMC neurons. a To the left are the membrane current tracings showing the spontaneous mEPSCs recorded in a vehicle-treated ARC neuron at baseline and following exposure to $1 \mu \mathrm{M}$ WIN 55,212-2. The bottom traces represent excerpts from expanded portions of their respective upper traces that are contained within the bracket. To the right lies the cumulative probability plot illustrating the increase in interval (inverse of frequency) between contiguous mEPSCs. WIN 55,212-2 elicited an approximately 51\% decrease in mEPSC frequency ( 2.9 vs. $6.0 \mathrm{~Hz}$ under basal conditions). b To the left are the membrane current tracings showing spontaneous mEPSCs in a cell perfused with $100 \mathrm{nM} \mathrm{E}_{2}$ at baseline and following exposure to $1 \mu \mathrm{M}$ WIN 55,212-2. To the right is the cumulative probability plot illustrating the interval between contiguous mEPSCs that substantiates the attenuated cannabinoid effect in this $\mathrm{E}_{2}$-treated slice. $\mathbf{c}$ The double labeling of the cells observed in a (top) and $\mathbf{b}$ (bottom). The cell in $\mathbf{a}$ is presumably coupled. (1) Color photomicrographs of the biocytin-streptavidin-AF488 labeling seen in these ARC neurons. (2) Color photomicrographs of the $\alpha$-MSH (top) and CART (bottom) immunofluorescence in the perikarya of the cells on the left as visualized with AF546. (3) Composite overlay illustrating the double labeling in these ARC neurons. d Composite dose-response curves for the decrease in mEPSC frequency produced by WIN 55,212-2 in ARC neurons from ethanol vehicle-treated (closed circle) and $\mathrm{E}_{2}$-treated (open circle) slices $(n=4-17)$. The curves were fit via logistic equation to the data points. Symbols represent means and vertical lines 2 SEM of the mEPSC frequency seen with varying concentrations of WIN 55,212-2 that were normalized to their respective control values. ${ }^{*}$ Distribution of the mEPSC interval in the presence of WIN 55,212-2 that is significantly different (KolmogorovSmirnov test, $\mathrm{p}<0.05$ ) than that observed under basal conditions. 


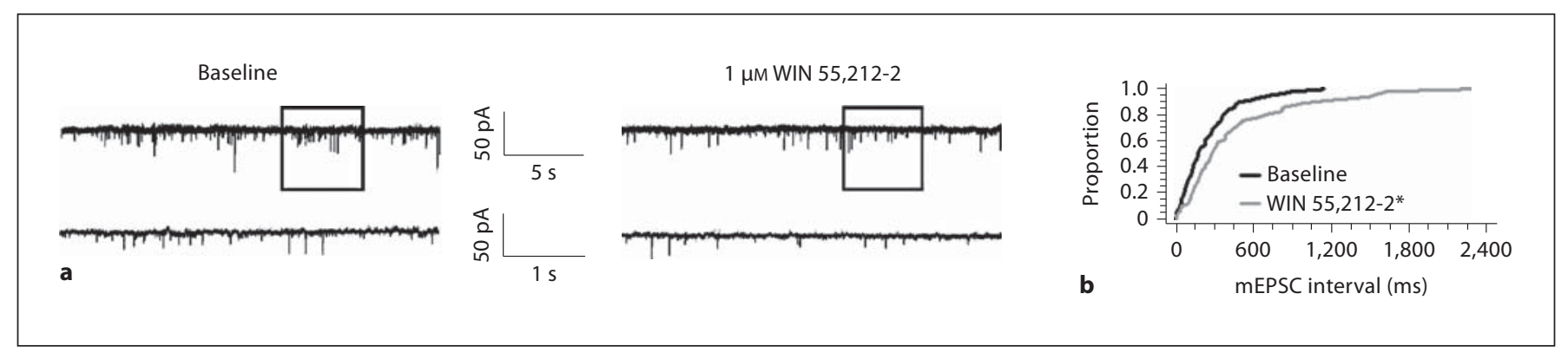

Fig. 6. 17 $\alpha$-estradiol does not affect the cannabinoid-induced presynaptic inhibition of glutamatergic synaptic input onto POMC neurons. a Spontaneous mEPSCs in a cell perfused with $100 \mathrm{nM} 17 \alpha$-estradiol at baseline (left) and following exposure to $1 \mu \mathrm{M}$ WIN 55,212-2 (right). b The cumulative probability plot illustrating the interval between contiguous mEPSCs that substantiates the inability of $17 \alpha$-estradiol to attenuate the inhibitory effect of WIN 55,212-2 on mEPSC frequency. * Distribution of the mEPSC interval in the presence of WIN 55,212-2 that is significantly different (Kolmogorov-Smirnov test, $\mathrm{p}<0.05$ ) than that observed under basal conditions. $\mathrm{c}$ The composite bar graph illustrating the stereospecificity of the $\mathrm{E}_{2}$-induced diminution of the decrease in mEPSC frequency caused by WIN 55,212-2. Bars represent means and vertical lines 1 SEM of the cannabinoid receptor agonist-induced decrease in mEPSC frequency normalized to baseline control conditions. ${ }^{*}$ Values measured in $\mathrm{E}_{2}$-treated slices that are significantly different (Kruskal-Wallis test/median-notched box and whisker plot; $\mathrm{p}<0.05$; $\mathrm{n}=5-8$ ) than those measured in the other treatment conditions.

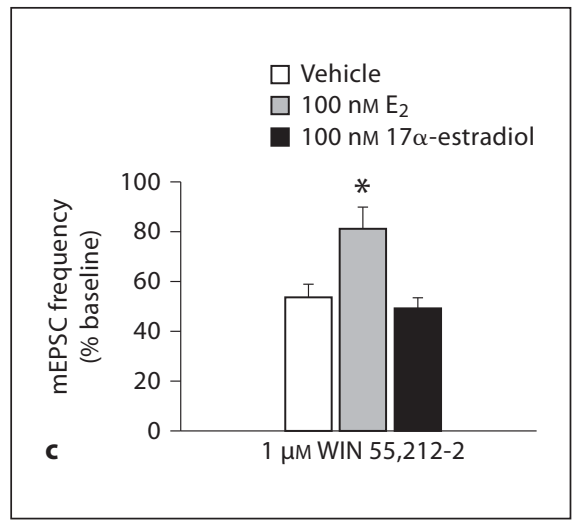

systemically $24 \mathrm{~h}$ prior to experimentation likewise disrupts the decrease in mEPSC frequency [34]. And although PPT failed to rapidly attenuate this cannabinoid-induced presynaptic inhibition, the possibility certainly exists that it could do so when delivered systemically 1 day earlier especially considering that PPT per se decreased daily food intake $24 \mathrm{~h}$ after administration, and abolished the cannabinoid-induced increase in food intake seen at $4 \mathrm{~h}$, after administration. As shown in figure 11, PPT (200 $\mu$ g; s.c.) given $24 \mathrm{~h}$ prior to experimentation nullified the reduction in mEPSC frequency produced by WIN 55,212-2.

\section{Discussion}

Taken together, these data indicate that both the $\mathrm{G}_{\mathrm{q}}$ coupled mER and ER $\alpha$ (but not ER $\beta$ or GPR30) contribute to the rapid and sustained, estrogenic impairment of cannabinoid-induced changes in energy homeostasis. The $G_{\mathrm{q}}$-coupled mER clearly triggers the rapid effects that occur within minutes, whereas ER $\alpha$ participates in the more prolonged attenuation. These conclusions are based on the following observations: (1) EB, the ER $\alpha$-selective ligand PPT, the $\mathrm{G}_{\mathrm{q}}$-coupled $\mathrm{mER}$-selective ligand STX, and the GPR30-selective ligand G-1 all decrease food intake per se, whereas the ER $\beta$-selective agonist DPN does not; (2) the cannabinoid receptor agonist WIN 55,212-2 increases food intake, and decreases $\mathrm{O}_{2}$ consumption and $\mathrm{CO}_{2}$ production; (3) EB, STX, and PPT all antagonize elevations in intake caused by the cannabinoid receptor agonist WIN 55,212-2 (EB and STX within $1 \mathrm{~h}$; PPT within $4 \mathrm{~h}$ ), whereas G-1 does not; (4) $\mathrm{E}_{2}$ and STX, but not $17 \alpha$-estradiol, PPT or G-1, rapidly impede the cannabinoid-induced presynaptic inhibition of glutamatergic input onto anorexigenic POMC neurons, and (5) systemically administered PPT reversed the cannabinoid-mediated decrease in glutamatergic neurotransmission at POMC synapses.

It is well established that CB1 receptor agonists stimulate appetite in humans $[37,38]$ and rodent animal models $[19,39,40]$. We have previously demonstrated that the cannabinoid-induced hyperphagia observed in our guinea pig animal model is associated with hypothermia [19, $20]$, and here we show that the increase in appetite correlates with reductions in two additional indices of energy expenditure - namely, $\mathrm{O}_{2}$ consumption and $\mathrm{CO}_{2}$ production. Despite a previous report that cannabinoids do not modulate appetite via POMC neurons in transgenic $\mathrm{A}^{\mathrm{y}}$ mice [41], the previous work from our lab, as well as others, has revealed that $\mathrm{CB} 1$ receptor activation decreases 


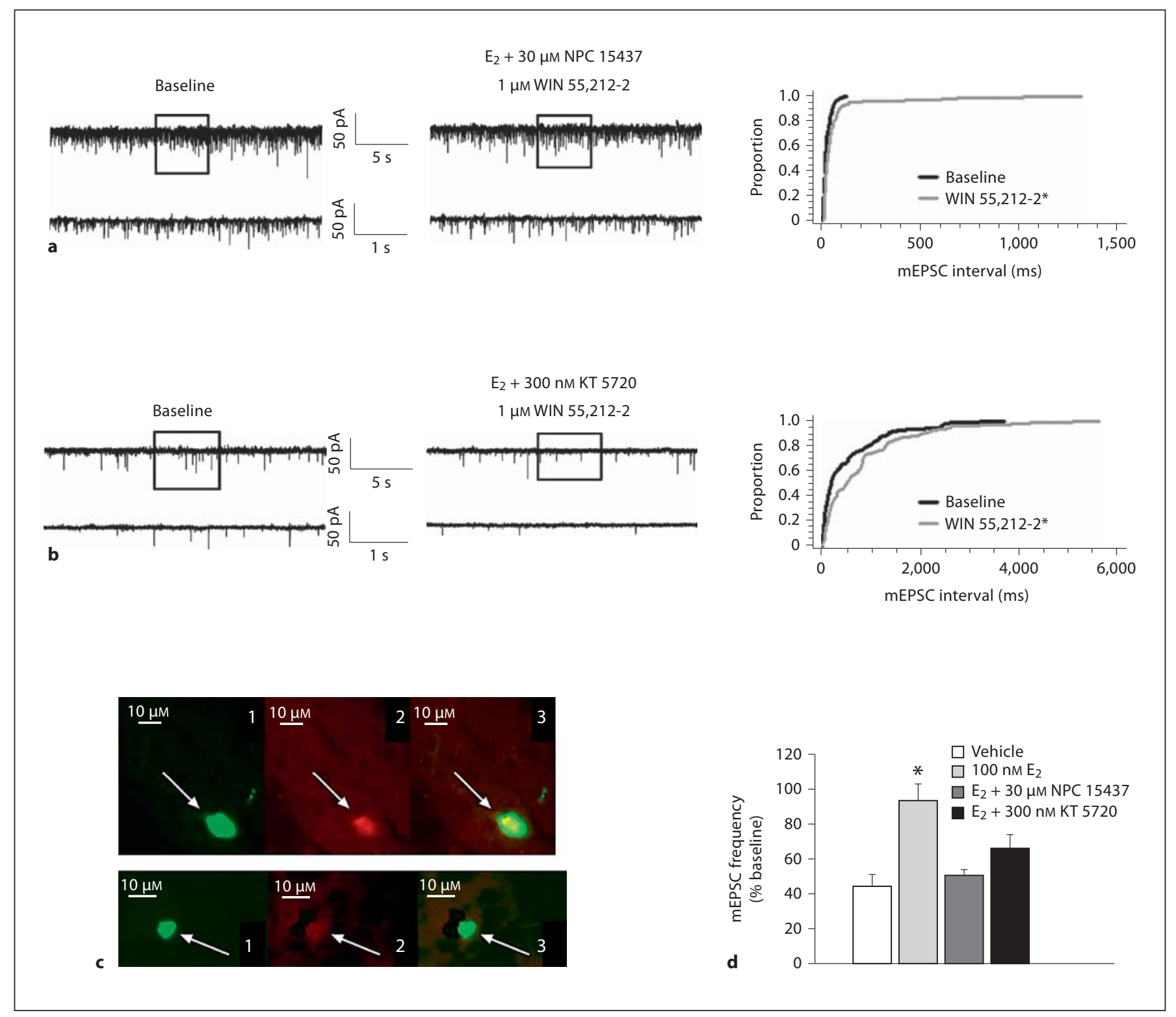

Fig. 7. PKC and PKA inhibition with NPC 15437 and KT 5720, respectively, at least partially prevents the $\mathrm{E}_{2}$-induced antagonism of cannabinoid-evoked decreases in glutamatergic input onto POMC neurons. a To the left are the spontaneous mEPSCs recorded in an ARC neuron treated with $100 \mathrm{nM} \mathrm{E}_{2}$ and $30 \mu \mathrm{M} \mathrm{NPC}$ 15437 at baseline and following exposure to $1 \mu \mathrm{M}$ WIN 55,212-2. To the right is the cumulative probability plot illustrating the ability of NPC 15437 to restore the cannabinoid receptor agonist-induced decrease in mEPSC frequency. ${ }^{*}$ Distribution of the mEPSC interval in the presence of WIN 55,212-2 that is significantly different (Kolmogorov-Smirnov test, $\mathrm{p}<0.05$ ) than that observed under basal conditions. $\mathbf{b}$ To the left are the spontaneous mEPSCs in a cell perfused with $\mathrm{E}_{2}$ and $300 \mathrm{nM} \mathrm{KT} 5720$ at baseline and following exposure to $1 \mu \mathrm{M}$ WIN 55,212-2. To the right is the cumulative probability plot illustrating the interval between contiguous mEPSCs that demonstrates the lack of steroid effect in the KT 5720 -treated slice. ${ }^{*}$ Distribution of the mEPSC interval in the presence of WIN 55,212-2 that is significantly different (Kolmogorov-Smirnov test, $\mathrm{p}<0.05$ ) than that observed under basal conditions. c The double labeling of the neurons observed in a (top) and $\mathbf{b}$ (bottom). (1) refers to the biocytin-streptavidinAF488 labeling, (2) depicts the $\beta$-endorphin immunofluorescence visualized by AF546, and (3) shows composite overlay. d This composite bar graph illustrates the efficacy of NPC 15437 and KT 5720 to block the $\mathrm{E}_{2}$-induced impairment of the cannabinoid-evoked decrease in mEPSC frequency. Bars represent means and vertical lines 1 SEM of the normalized decrease in mEPSC frequency in neurons from slices treated with $E_{2}$, either alone or in combination with NPC 15437 or KT $5720 .{ }^{*} \mathrm{E}_{2}$-induced changes in the cannabinoid-evoked decrease in $\mathrm{MEPSC}$ frequency that are significantly different (Kruskal-Wallis test/median-notched box and whisker plot; $\mathrm{p}<0.05 ; \mathrm{n}=5-15)$ than those measured in the other treatment conditions. 


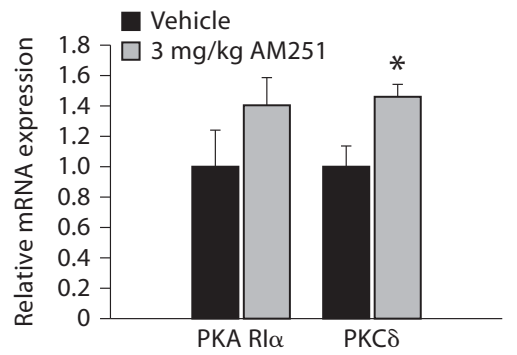

Fig. 8. The effects of the CB1 receptor antagonist AM251 on PKA $\mathrm{RI} \alpha$ and $\mathrm{PKC} \delta$ expression in the ARC. Bars represent means and vertical lines 1 SEM of the mRNA expression determined in ARC tissue harvested after 7 days of treatment with AM251 (3 mg/kg; s.c.) or its cremephor/ethanol $/ 0.9 \%$ saline vehicle $(0.1 \mathrm{ml}$; s.c.). * Values measured in AM251-treated animals that are significantly different (Mann-Whitney U test; $\mathrm{p}<0.05 ; \mathrm{n}=4-9$ ) than those measured in vehicle-treated controls.

excitatory glutamatergic neurotransmission at POMC synapses $[34,42,43]$. Furthermore, the activation of central melanocortin receptors not only decreases appetite but also increases energy expenditure and uncoupling protein 1 (UCP1) expression in adipose tissue [44, 45]. These latter findings are paralleled by the fact that blockade of central CB1 receptors not only increases excitatory glutamatergic neurotransmission at POMC synapses, but also increases energy expenditure and UCP1 expression in adipose tissue $[34,43,46]$. It would appear, therefore, that cannabinoid-induced effects on energy balance can be attributed, at least in part, to the inhibition of POMC neuronal activity and melanocortin signaling.

It is also well known that estrogens decrease energy intake in rodents $[15,47]$, and in human females consumption is at its lowest during the periovulatory phase of the menstrual cycle - when estrogen levels are at their highest [16]. In the present study, both STX and PPT (but not DPN) decreased intake, which is consistent with previous studies demonstrating a role for the $\mathrm{G}_{\mathrm{q}}$-coupled mER and ER $\alpha$ (but not ER $\beta$ ) in regulating energy balance $[18,22,48]$. Most interestingly, we observed that both STX and PPT abolished the cannabinoid-induced hyperphagia - albeit on a different time course. STX completely blocked the hyperphagic response within $1 \mathrm{~h}$, whereas PPT took up to $4 \mathrm{~h}$ following administration. The comparatively slower response following ER $\alpha$ activation with PPT is somewhat puzzling. $\mathrm{ER} \alpha$ is expressed in the plasma membrane of cultured rat hypothalamic neurons [49], and a 1-hour incubation with either $\mathrm{E}_{2}$ or PPT decreases $\mathrm{K}^{+}$-stimulated neuropeptide $\mathrm{Y}$ secretion in neuronal cell models (i.e. mHypoE-42 and mHypoA-2/12) [50]. However, the vast majority of ER $\alpha$ expressed in POMC neurons from ovariectomized female guinea pigs is localized to the nucleus and/or cytoplasm [27]. Coupled with the fact that $\mathrm{E}_{2}$ itself is required for the induction of ER $\alpha$ trafficking to the plasma membrane [49], this may help to explain the comparative lag time between the response to $\mathrm{G}_{\mathrm{q}}$-coupled $\mathrm{mER}$ and $\mathrm{ER} \alpha$ activation. In any case, our data point to an important interaction between the $\mathrm{G}_{\mathrm{q}}$-coupled $\mathrm{mER}$ and the ER $\alpha$ in negatively modulating cannabinoid-induced hyperphagia. Interestingly, we found that while GPR30 activation also reduced food intake, it failed to appreciably influence cannabinoid receptor-mediated increases in consumption. GPR30 colocalizes with neurosecretory cells in the hypothalamic paraventricular nucleus, including corticotropin-releasing hormone $(\mathrm{CRH})$ neurons, and participates in desensitizing $5 \mathrm{HT}_{1 \mathrm{~A}}$ receptormediated increases in adrenocorticotropin secretion from the anterior pituitary [13]. Given that CRH neurons represent an important anorexigenic component of the hypothalamic feeding circuitry [51], it appears that GPR30 activation suppresses appetite via this neuroanatomical substrate. This suggests that mechanisms other than suppression of cannabinoid signaling within the hypothalamic feeding circuitry can also contribute to the estrogenic reduction in energy intake.

In addition to abrogating the cannabinoid-induced hyperphagia and hypothermia [20], we have previously shown that estrogens dramatically blunt the cannabinoid-induced, presynaptic inhibition of glutamate release at POMC synapses in a rapid and sustained fashion via an ER-mediated mechanism [7, 34]. Collectively, these findings are consistent with those of Riebe et al. [21], who showed that estrogens downregulate hypothalamic CB1 receptors. In the present study, we observed that this negative modulatory effect of $E_{2}$ was stereoselective, as bath application of $17 \alpha$-estradiol had no effect on the cannabinoid receptor-mediated decrease in glutamatergic input onto POMC neurons. Given that $17 \alpha$-estradiol is the preferred ligand for ER-X [14], this would indicate that this ER subtype, as with ER $\beta$ and GPR30, is not involved in the estrogenic antagonism of the cannabinoid regulation of energy homeostasis. In addition, we discovered that inhibition of PKC completely restores the ability of cannabinoids to presynaptically decrease glutamate release onto POMC neurons, whereas inhibition of PKA is partially effective in this regard. The concentration of KT 


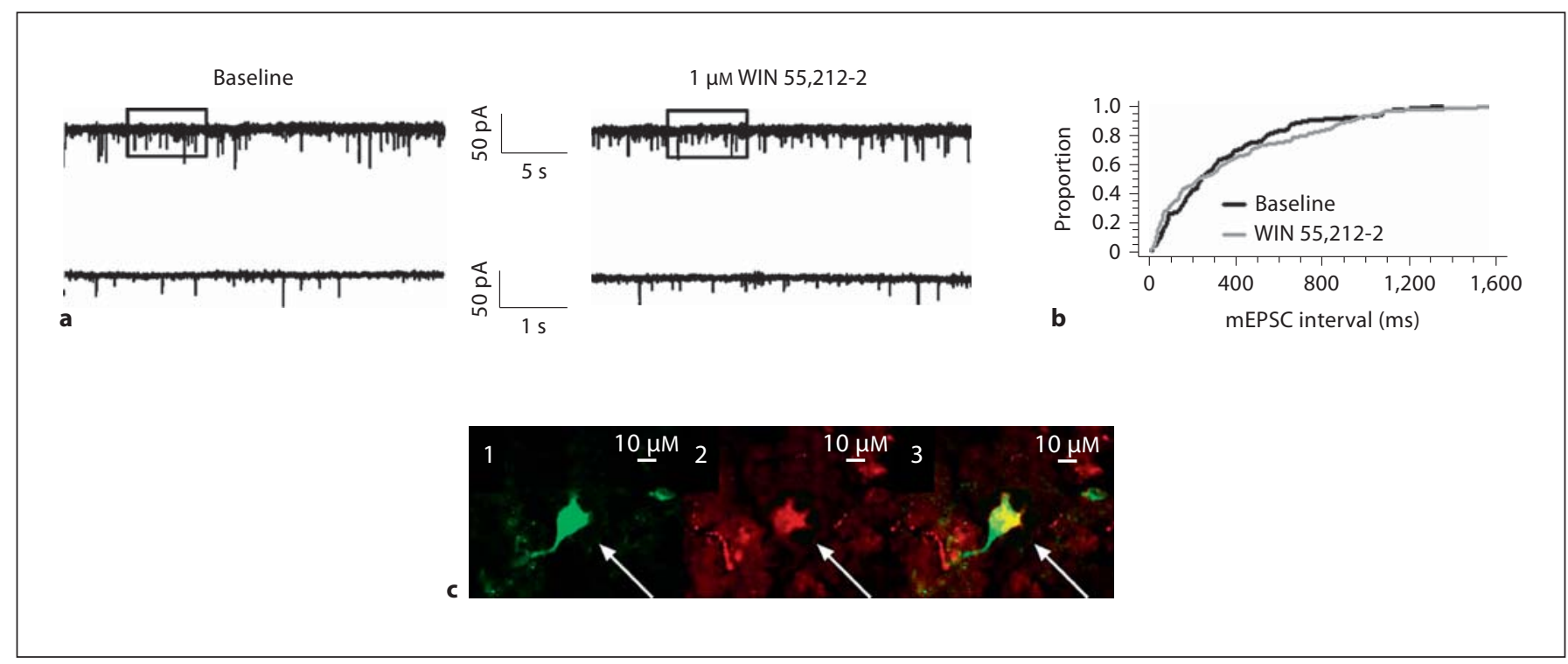

Fig. 9. STX antagonizes the cannabinoid-induced decrease in glutamatergic input onto POMC neurons. a Spontaneous mEPSCs in a cell perfused with $10 \mathrm{nM}$ STX at baseline and following exposure to $1 \mu \mathrm{M}$ WIN $55,212-2$. b The cumulative probability plot illustrating the interval between contiguous mEPSCs that substanti- ates the ability of STX to attenuate the inhibitory effect of WIN $55,212-2$ on mEPSC frequency. c Photomicrographs that illustrate the double labeling of the cell. (1) Biocytin-streptavidin-AF488 labeling. (2) $\alpha-\mathrm{MSH}$ immunofluorescence visualized by AF546. (3) Composite overlay.
5720 used in the present study is still highly selective for PKA despite being approximately $5 \times$ higher than the reported $\mathrm{K}_{\mathrm{i}}$ [32]. Moreover, CB1 receptor antagonism upregulates $\mathrm{ARC} \mathrm{PKC} \delta$ expression, but produces only a modest, statistically insignificant increase of the expression of PKA R1 $\alpha$. These findings would suggest that PKC plays a critical role, whereas PKA plays an ancillary role, in the estrogenic attenuation of $\mathrm{CB} 1$ receptor-mediated changes in energy balance.

Nevertheless, this functional antagonism of the cannabinoid system is in agreement with how estrogens rapidly uncouple metabotropic $\mu$-opioid and $\mathrm{GABA}_{\mathrm{B}}$ receptors from their GIRK channels in POMC neurons, which occurs via the activation of the $\mathrm{G}_{\mathrm{q}}$-coupled $\mathrm{mER}$ and the subsequent activation of a PLC/PKC/PKA pathway [1]. Our findings provide further evidence that this negative estrogenic modulation of the function of $\mathrm{G}_{\mathrm{i} / \mathrm{o}}$-coupled receptors is not restricted to the postsynaptic membrane, and indeed can extend to upstream glutamatergic nerve terminals that influence the excitability of anorexigenic POMC neurons. Taking into consideration that the estrogen-induced impairment of the function of presynaptically and postsynaptically localized $\mathrm{G}_{\mathrm{i} / \mathrm{o}}$-coupled receptors also involves alterations in the activity of PI3K and AMP-activated kinase $[7,28]$, these findings provide ad- ditional critical insight that advances our understanding of, and appreciation for, the complexity of the signal transduction mechanism(s) that underlie this process. This ER-mediated signaling that disrupts the cannabinoid regulation of energy balance may be initiated upstream of the POMC neuron - at the nerve terminal membrane of glutamatergic inputs arising from the hypothalamic ventromedial nucleus [52]. Alternatively, it could be generated postsynaptically and perhaps lead to the formation of a diffusible retrograde messenger like nitric oxide [53] that ultimately disrupts $\mathrm{CB} 1$ receptor/effector coupling. Future studies will determine if this is in fact the case.

We also found that similar to $E_{2}$, activation of the $G_{q^{-}}$ coupled mER upon bath application of STX for 10-15 min powerfully disrupted cannabinoid signaling at POMC synapses. However, this was not the case for the activation of ER $\alpha$ with PPT or GPR30 with G-1. We know that the estrogenic diminution of the cannabinoid-induced decrease in glutamate release at POMC synapses is quite prolonged; lasting at least $24 \mathrm{~h}$ following systemic administration of EB [34]. In the present study, we found that although activation of ER $\alpha$ during bath application of PPT failed to rapidly alter this reduction in excitatory glutamatergic synaptic input, ablation of the resultant can- 


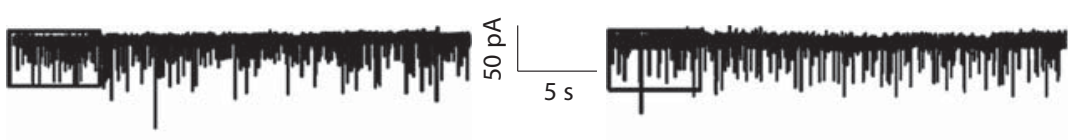

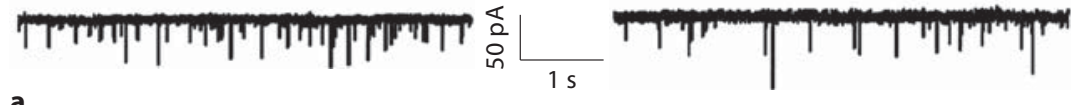

$3 \mu \mathrm{M}$ G-1

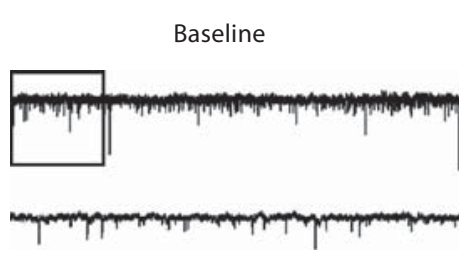

b
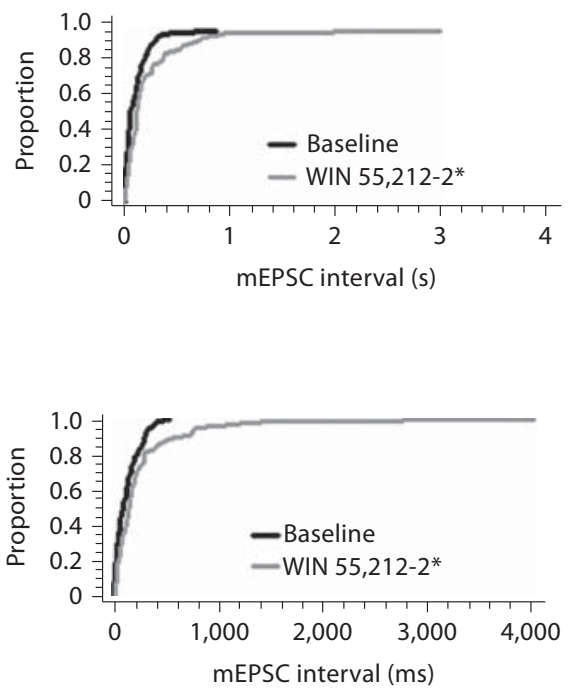

Fig. 10. Neither PPT nor G-1 affects the cannabinoid-induced inhibition of glutamatergic synaptic input. a To the left are the spontaneous mEPSCs in a cell perfused with $1 \mu \mathrm{M}$ PPT at baseline and following exposure to $1 \mu \mathrm{M}$ WIN 55,212-2. To the right is the cumulative probability plot illustrating the interval between contiguous mEPSCs that substantiates the inability of PPT to attenuate the inhibitory effect of WIN 55,212-2 on mEPSC frequency. * Distribution of the mEPSC interval in the presence of WIN 55,212-2 that is significantly different (Kolmogorov-Smirnov test, $\mathrm{p}<0.05)$ than that observed under basal conditions. $\mathbf{b}$ To the left are the spontaneous mEPSCs in a cell perfused with $3 \mu \mathrm{M} \mathrm{G}-1$ at baseline and following exposure to $1 \mu \mathrm{M}$ WIN 55,212-2. To the right is the cumulative probability plot illustrating the lack of effect of G-1 in diminishing the cannabinoid-induced decrease in mEPSC frequency. ${ }^{*}$ Distribution of the mEPSC interval in the presence of WIN 55,212-2 that is significantly different (Kolmogorov-Smirnov test, $\mathrm{p}<0.05$ ) than that observed under basal conditions. c The composite bar graph illustrating the efficacy of ER ligands to impede the decrease in mEPSC frequency caused by WIN 55,212-2. Bars represent means and vertical lines 1 SEM of the normalized, cannabinoid receptor agonist-induced decrease in mEPSC frequency. ${ }^{*}$ Values measured in $\mathrm{E}_{2}$ - and STX-treated slices that are significantly different (Kruskal-Wallis test/median-notched box and whisker plot; $\mathrm{p}<0.05 ; \mathrm{n}=3-9$ ) than those measured in the other treatment conditions.

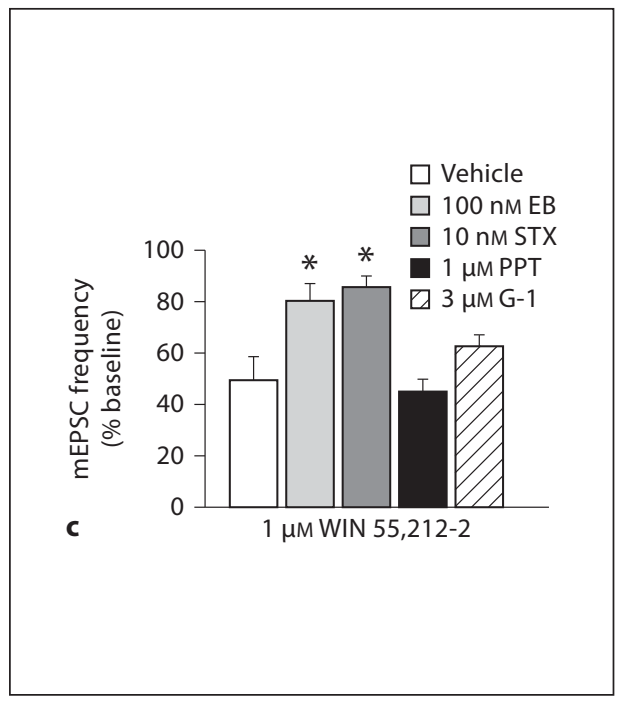

nabinoid receptor-mediated inhibition of POMC neurons was observed over the longer term upon systemic delivery $24 \mathrm{~h}$ prior to experimentation. This is in keeping with the time course of the effects of ER $\alpha$ activation that we saw for basal and cannabinoid-stimulated food intake.

The disparate effect of cannabinoids on energy homeostasis in males and females is consistent with numerous other reports detailing sex differences in cannabinoid-regulated biology. However, the direction of the sex difference, and how they are modulated by gonadal ste- roids, depends on the system being impacted. For example, female rats are more sensitive than their male counterparts to the antinociceptive effects of cannabinoids in response to noxious thermal and mechanical stimuli [54, 55], as well as the cannabinoid-induced hyperlocomotion and catalepsy [54-56]. Estradiol enhances the cannabinoid-induced antinociception, whereas testosterone attenuates the cannabinoid-induced catalepsy [57]. In addition, women are more susceptible to the cannabinoid-induced hemodynamic changes observed with the 


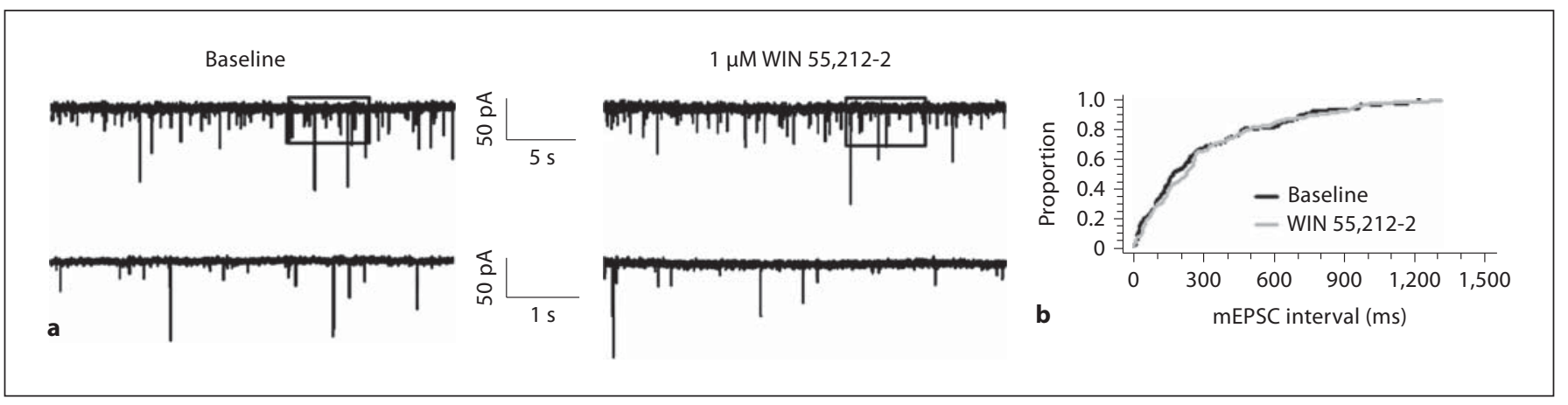

Fig. 11. Longer-term treatment with systemic PPT abrogates the cannabinoid-induced decrease in glutamatergic synaptic input. a Spontaneous mEPSCs in a cell from an animal treated $24 \mathrm{~h}$ prior with PPT (200 $\mu$ g; s.c.) at baseline and following exposure to $1 \mu \mathrm{M}$ WIN 55,212-2. b The cumulative probability plot that substantiates the efficacy of systemic PPT in attenuating the inhibitory effect of WIN 55,212-2 on mEPSC frequency. c The composite bar graph illustrating the ability of systemic PPT to diminish the normalized decrease in mEPSC frequency caused by WIN 55,212-2. Bars represent means and vertical lines 1 SEM of the decrease in mEPSC frequency elicited by $1-3 \mu \mathrm{M}$ WIN 55,212-2. *Values measured in neurons from PPT-treated animals that are significantly different (Kruskal-Wallis test/median-notched box and whisker plot; $\mathrm{p}<0.05 ; \mathrm{n}=7-12$ ) than those obtained from vehicle-treated controls.

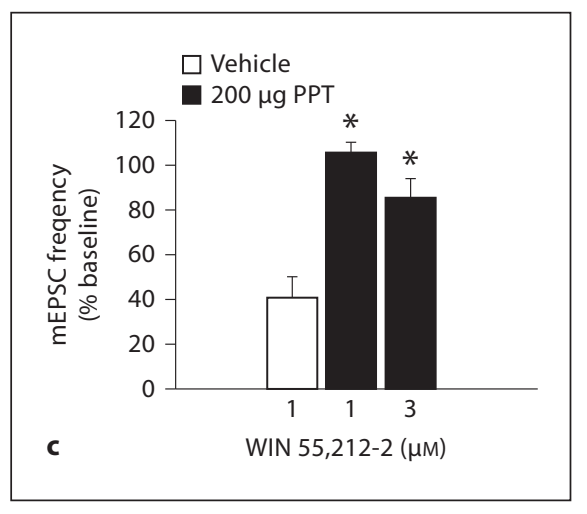

transition between the supine and standing position [58], and are more vulnerable to the cannabinoid-induced impairment of visuospatial memory [59] than their male counterparts. Moreover, adolescent exposure to CB1 receptor agonists will differentially alter cannabinoid-induced changes in food intake, growth trajectory, locomotion, emotional reactivity and memory, as well as $\mathrm{CB} 1$ receptor density and agonist-stimulated $\left[{ }^{35} \mathrm{~S}\right] \mathrm{GTP} \gamma \mathrm{S}$ binding in the limbic system and ventral tegmental area, of males and females when evaluated in adulthood [6062]. On the other hand, male rats are more sensitive to the stimulatory effect of the centrally administered CB1 receptor agonist CP 55,940 on the consumption of sweetened condensed milk [63]; a dose $10 \times$ higher is required to elicit an equivalent intake in females, which is congruent with the cannabinoid-induced changes in energy homeostasis that we see in the guinea pig.

Thus, it is clear that POMC neurons are a major focal point in the estrogenic regulation of energy homeostasis. Estrogens promote formation of excitatory synapses making contact with POMC perikarya [47], and upregulate the expression of GluR1-3 receptors [64]. They also increase POMC expression [27] and increase the release of POMC-derived peptides [65]. These latter effects can be attributed to the ER-mediated attenuation of the cou- pling of presynaptic and postsynaptic metabotropic receptors to their effector systems $[1,7,28]$. In the considerable majority of studies touting the therapeutic efficacy of cannabinoid agonists to stimulate appetite, promote weight gain, reduce nausea and relieve pain, the gender ratio of participants was markedly skewed towards men [66-69]. However, in the one study in which the gender ratio was more equitable, the ability of cannabinoids to affect changes in appetite was much less impressive [70]. Thus, it follows that the results of the present study further solidify the idea that the cannabinoid system is a critical component targeted and antagonized by estrogens, which contributes to the activation of POMC neurons and the formation of a negative energy balance, and helps to explain why females are less sensitive than males to cannabinoid effects on energy homeostasis [19].

In conclusion, these results reveal that estrogen exerts rapid, negative modulatory influences on the cannabinoid regulation of energy balance. They also uncover an important interaction between the $\mathrm{G}_{\mathrm{q}}$-coupled mER and ER $\alpha$ in suppressing basal and cannabinoid-stimulated food intake, as well as CB1 receptor-mediated activation in glutamatergic nerve terminals and subsequent inhibition of POMC neurons via activation of PKC and PKA. The $\mathrm{G}_{\mathrm{q}^{-}}$ coupled mER mediates the initial rapid phase, whereas 
ER $\alpha$ participates by prolonging and sustaining the antagonism of the cannabinoid-induced hyperphagia and signaling at POMC synapses. The data provide additional insight into the interaction between estrogen and cannabinoids in the hypothalamic regulation of energy homeostasis, as well as a heightened appreciation for the gender differences in the therapeutic efficacy of cannabinoids.

\section{Acknowledgements}

The authors thank Lindsay Pietruszewski for her technical assistance. This study was supported by PHS Grants DA024314, HD058638 (sub-contract to EJW), NS38809 and DK68098, and an intramural research grant from Western University of Health Sciences.

\section{References}

1 Qiu J, Rønnekleiv OK, Kelly MJ: Modulation of hypothalamic neuronal activity through a novel G-protein-coupled estrogen receptor. Steroids 2008;73:985-991.

-2 Boulware MI, Kordasiewicz H, Mermelstein PG: Caveolin proteins are essential for distinct effects of membrane estrogen receptors in neurons. J Neurosci 2007;27:9941-9950.

- 3 Dewing P, Christensen A, Bondar G, Micevych PE: Protein kinase $C$ signaling in the hypothalamic arcuate nucleus regulates sexual receptivity in female rats. Endocrinology 2008;149:5934-5942.

4 Matsuoka H, Tsubaki M, Yamazoe Y, Ogaki M, Satou T, Itoh T, Kusunoki T, Nishida S: Tamoxifen inhibits tumor cell invasion and metastasis in mouse melanoma through suppression of PKC/MEK/ERK and PKC/PI3K/ Akt pathways. Exp Cell Res 2009;315:20222032.

5 Li L, Haynes P, Bender JR: Plasma membrane localization and function of the estrogen receptor $\alpha$ variant (ER46) in human endothelial cells. Proc Natl Acad Sci USA 2003;100: 4807-4812.

6 Boulware MI, Weick JP, Becklund BR, Kuo SP, Groth RD, Mermelstein PG: Estradiol activates group I and II metabotropic glutamate receptor signaling, leading to opposing influences on cAMP response element-binding protein. J Neurosci 2005;25:5066-5078.

7 Jeffery GS, Peng KC, Wagner EJ: The role of phosphatidylinositol-3-kinase and AMP-activated kinase in the rapid estrogenic attenuation of cannabinoid-induced changes in energy homeostasis. Pharmaceuticals 2011;4: 630-651.

8 Kuo J, Hamid N, Bondar G, Prossnitz ER, Micevych PE: Membrane estrogen receptors stimulate intracellular calcium release and progesterone synthesis in hypothalamic astrocytes. J Neurosci 2010;30:12950-12957.

9 Gingerich S and Krukoff TL: Activation of ER $\beta$ increases levels of phosphorylated nNOS and NO production through a Src/ PI3K/Akt-dependent pathway in hypothalamic neurons. Neuropharmacology 2008; 55:878-885

10 Chu Z, Andrade J, Shupnik MA, Moenter SM: Differential regulation of gonadotropinreleasing hormone neuron activity and membrane properties by acutely applied es- tradiol: dependence on dose and estrogen receptor subtype. J Neurosci 2009;29:56165627.

-11 Michaeli A, Yaka R: Dopamine inhibits $\mathrm{GABA}_{\mathrm{A}}$ currents in ventral tegmental area dopamine neurons via activation of presynaptic G-protein coupled inwardly-rectifying potassium channels. Neuroscience 2010;165: 1159-1169.

12 Lebesgue D, Reyna-Neyra A, Huang X, Etgen AM: GPR30 differentially regulates short latency responses of luteinizing hormone and prolactin secretion to oestradiol. J Neuroendocrinol 2009;21:743-752.

13 Xu H, Qin S, Carrasco GA, Dai Y, Filardo EJ, Prossnitz ER, Battaglia G, DonCarlos LL, Muma NA: Extra-nuclear estrogen receptor GPR30 regulates serotonin function in rat hypothalamus. Neuroscience 2009;158: 1599-1607.

14 Toran-Allerand CD: Estrogen and the brain: beyond ER- $\alpha$, ER- $\beta$, and $17 \beta$-estradiol. Ann NY Acad Sci 2005;1052:136-144.

15 Butera PC, Czaja JA: Intracranial estradiol in ovariectomized guinea pigs: effects on ingestive behaviors and body weight. Brain Res 1984:322:41-48.

16 Johnson WG, Corrigan SA, Lemmon CR, Bergeron KB, Crusco AH: Energy regulation over the menstrual cycle. Physiol Behav 1994;56:523-527.

17 Stephenson LA, Kolka MA: Esophageal temperature threshold for sweating decreases before ovulation in premenopausal women. J Appl Physiol 1999;86:22-28.

18 Roepke TA, Bosch MA, Rick EA, Lee B, Wagner EJ, Seidlova-Wuttke D, Wuttke W, Scanlan TS, Rønnekleiv OK, Kelly MJ: Contribution of a membrane estrogen receptor to the estrogenic regulation of body temperature and energy homeostasis. Endocrinology 2010;151:4926-4937.

19 Farhang B, Diaz S, Tang SL, Wagner EJ: Sex differences in the cannabinoid regulation of energy homeostasis. Psychoneuroendocrinology 2009;34S:S237-S246.

20 Kellert BA, Nguyen MC, Nguyen C, Nguyen $\mathrm{QH}$, Wagner EJ: Estrogen rapidly attenuates cannabinoid-induced changes in energy homeostasis. Eur J Pharmacol 2009;622:15-24.

21 Riebe CJN, Hill MN, Lee TTY, Hillard CJ, Gorzalka BB: Estrogenic regulation of limbic cannabinoid receptor binding. Psychoneuroendocrinology 2010;35:1265-1269.

22 Santollo J, Wiley MD, Eckel LA: Acute activation of $\mathrm{ER} \alpha$ decreases food intake, meal size and body weight in ovariectomized rats. Am J Physiol Regul Integr Comp Physiol 2007;293:R2194-R2201.

- 23 Lindsey SH, Yamaleyeva LM, Brosnihan KB Gallagher PE, Chappell MC: Estrogen receptor GPR30 reduces oxidative stress and proteinuria in the salt-sensitive female mRen2. Lewis rat. Hypertension 2011;58:665-671.

24 Tindal JS: The forebrain of the guinea pig in stereotaxic coordinates. J Comp Neurol 1965;124:259-266.

25 Qiu J, Bosch MA, Tobias SC, Grandy DK Scanlan TS, Rønnekleiv OK, Kelly MJ: Rapid signaling of estrogen in hypothalamic neurons involves a novel G-protein-coupled estrogen receptor that activates protein kinase C. J Neurosci 2003;23:9529-9540.

26 Chang A, Li PP, Warsh JJ: cAMP-Dependent protein kinase (PKA) subunit mRNA levels in postmortem brain from patients with bipolar affective disorder (BD). Mol Brain Res 2003;116:27-37.

27 Roepke TA, Malyala A, Bosch MA, Kelly MJ, Rønnekleiv OK: Estrogen regulation of genes important for $\mathrm{K}^{+}$channel signaling in the arcuate nucleus. Endocrinology 2007; 148:4937-4951.

28 Malyala A, Zhang C, Bryant DN, Kelly MJ, Rønnekleiv OK: PI3K signaling effects in hypothalamic neurons mediated by estrogen. J Comp Neurol 2008;506:895-911.

-29 Roepke TA, Xue C, Bosch MA, Scanlan TS, Kelly MJ, Rønnekleiv OK: Genes associated with membrane-initiated signaling of estrogen and energy homeostasis. Endocrinology 2008;149:6113-6124.

30 Kelly MJ, Moss RL, Dudley CA, Fawcett CP: The specificity of the response of preopticseptal area neurons to estrogen: $17 \alpha$-estradiol versus $17 \beta$-estradiol and the response of extrahypothalamic neurons. Exp Brain Res 1977;30:43-52.

- 31 Sullivan JP, Connor JR, Shearer BG, Burch RM: 2,6-Diamino-N-([1-(1-oxotridecyl)-2piperidinyl] methyl)hexanamide (NPC 15437): a novel inhibitor of protein kinase $C$ interacting at the regulatory domain. Mol Pharmacol 1992;41:38-44. 
- 32 Gadbois DM, Crissman HA, Tobey RA, Bradbury EM: Multiple kinase arrest points in the G1 phase of nontransformed mammalian cells are absent in transformed cells. Proc Natl Acad Sci USA 1992;89:8626-8630.

- 33 Lagrange AH, Ronnekleiv OK, Kelly MJ: Modulation of $\mathrm{G}$ protein-coupled receptors by an estrogen receptor that activates protein kinase A. Mol Pharmacol 1997;51:605-612.

-34 Nguyen QH, Wagner EJ: Estrogen differentially modulates the cannabinoid-induced presynaptic inhibition of amino acid neurotransmission in proopiomelanocortin neurons of the arcuate nucleus. Neuroendocrinology 2006;84:123-137.

-35 Blasko E, Haskell CA, Leung S, Gualtieri G, Halks-Miller M, Mahmoudi M, Dennis MK, Prossnitz ER, Karpus WJ, Horuk R: Beneficial role of the GPR30 agonist G-1 in an animal model of multiple sclerosis. J Neuroimmunol 2009;214:67-77.

- 36 Intapad S, Dimitropoulou C, Snead C, Piyachaturawat P, Catravas JD: Regulation of asthmatic airway relaxation by estrogen and heat shock protein 90. J Cell Physiol 2012; 227:3036-3043.

37 Mattes RD, Engelman K, Shaw LM, Elsohly 5 MA: Cannabinoids and appetite stimulation. Pharmacol Biochem Behav 1994;49: 187-195.

-38 Budney AJ, Hughes JR, Moore BA, Novy PL: Marijuana abstinence effects in marijuana smokers maintained in their home environment. Arch Gen Psychiatry 2001;58:917-924.

-39 Williams CM, Rogers PJ, Kirkham TC: Hyperphagia in pre-fed rats following oral $\Delta^{9}$ THC. Physiol Behav 1998;65:343-346.

40 Koch JE: $\Delta^{9}$-THC stimulates food intake in Lewis rats: effects on chow, high-fat and sweet high-fat diets. Pharmacol Biochem Behav 2001;68:539-543.

-41 Sinnayah P, Jobst EE, Rathner JA, CalderaSiu AD, Tonelli-Lemos L, Eusterbrock AJ, Enriori PJ, Pothos EN, Grove KL, Cowley MA: Feeding induced by cannabinoids is mediated independently of the melanocortin system. PLoS ONE 2008;3:e2202.

42 Hentges ST, Low MJ, Williams JT: Differential regulation of synaptic inputs by constitutively released endocannabinoids and exogenous cannabinoids. J Neurosci 2005;25: 9746-9751.

43 Ho J, Cox JM, Wagner EJ: Cannabinoidinduced hyperphagia: correlation with inhibition of proopiomelanocortin neurons? Physiol Behav 2007;92:507-519.

-44 Glavas MM, Joachim SE, Draper SJ, Smith MS, Grove KL: Melanocortinergic activation by melanotan II inhibits feeding and increases uncoupling protein 1 messenger ribonucleic acid in the developing rat. Endocrinology 2007;148:3279-3287.

45 Verty ANA, Allen AM, Oldfield BJ: The endogenous actions of hypothalamic peptides on brown adipose tissue thermogenesis in the rat. Endocrinology 2010;151:4236-4246.
46 Verty ANA, Allen AM, Oldfield BJ: The effects of Rimonabant on brown adipose tissue in rat: implications for energy expenditure. Obesity 2008;17:254-261.

47 Gao Q, Mezei G, Nie Y, Rao Y, Choi CS, Bechmann I, Leranth C, Toran-Allerand D, Priest CA, Roberts JL, Gao X-B, Mobbs C, Shulman GI, Diano S, Horvath TL: Anorectic estrogen mimics leptin's effect on the rewiring of melanocortin cells and Stat 3 signaling in obese animals. Nat Med 2007;13:89-94.

48 Musatov S, Chen W, Pfaff DW, Mobbs CV, Yang XJ, Clegg DJ, Kaplitt MG, Ogawa S: Silencing of estrogen receptor $\alpha$ in the ventromedial nucleus of the hypothalamus leads to metabolic syndrome. Proc Natl Acad Sci USA 2007;104:2501-2506.

49 Dominguez R, Micevych PE: Estradiol rapidly regulates membrane estrogen receptor $\alpha$ levels in hypothalamic neurons. J Neurosci 2010;30:12589-12596.

50 Dhillon SS, Belsham DD: Estrogen inhibits NPY secretion through membrane-associated estrogen receptor (ER)- $\alpha$ in clonal, immortalized hypothalamic neurons. Int J Obesity 2011;35:198-207.

51 Horvath TL: The hardship of obesity: a softwired hypothalamus. Nat Neurosci 2005;8: 561-565.

52 Sternson SM, Shepherd GMG, Friedman JM: Topographic mapping of $\mathrm{VMH}$-arcuate nucleus microcircuits and their reorganization by fasting. Nat Neurosci 2005;8:1356-1363.

53 Schuman EM, Madison DV: A requirement for the intracellular messenger nitric oxide in long-term potentiation. Science 1991;254: 1503-1506.

54 Tseng AH, Craft RM: Sex differences in antinociceptive and motoric effects of cannabinoids. Eur J Pharmacol 2001;430:41-47.

55 Tseng AH, Harding JW, Craft RM: Pharmacokinetic factors in sex differences in $\Delta^{9}$-tetrahydrocannabinol-induced behavioral effects in rats. Behav Brain Res 2004;154:77-83.

56 Wiley JL: Sex-dependent effects of $\Delta^{9}$-tetrahydrocannabinol on locomotor activity in mice. Neurosci Lett 2003;352:77-80.

57 Craft RM, Leitl MD: Gonadal hormone modulation of the behavioral effects of $\Delta^{9}$ tetrahydrocannabinol in male and female rats. Eur J Pharmacol 2008;578:37-42.

58 Mathew RJ, Wilson WH, Davis R: Postural syncope after marijuana: a transcranial Doppler study of the hemodynamics. Pharmacol Biochem Behav 2003;75:309-318.

59 Pope HG, Jacobs A, Mialet J-P, YurgelunTodd D, Gruber S: Evidence for a sex-specific residual effect of cannabis on visuospatial memory. Psychother Psychosom 1997;66: 179-184.

60 Biscaia M, Mark GP, Fernández B, Marco EM, Rubio M, Guaza C, Ambrosio E, Viveros MP: Chronic treatment with CP 55,940 during the peri-adolescent period differentially affects the behavioral responses of male and female rats. Psychopharmacology (Berl) 2003;170:301-308.
61 Rubino T, Vigano D, Realini N, Guidali C, Braida D, Capurro V, Castiglioni C, Cherubino F, Romualdi P, Candeletti S, Sala M, Parolaro D: Chronic $\Delta^{9}$-tetrahydrocannabinol during adolescence provokes sex-dependent changes in the emotional profile in adult rats: behavioral and biochemical correlates. Neuropsychopharmacology 2008;33:27602771.

62 Mateos B, Borcel E, Loriga R, Luesu W, Bini V, Llorente R, Castelli MP, Viveros M-P: Adolescent exposure to nicotine and/or the cannabinoid agonist CP 55,940 induces genderdependent long-lasting memory impairments and changes in brain nicotinic and $\mathrm{CB}_{1}$ receptors. J Psychopharmacol 2011;25: 1676-1690.

63 Miller CC, Murray TF, Freeman KG, Edwards GL: Cannabinoid agonist, CP 55,940, facilitates intake of palatable foods when injected into the hindbrain. Physiol Behav 2004;80:611-616.

64 Diano S, Naftolin F, Horvath TL: Gonadal steroids target AMPA glutamate receptorcontaining neurons in the rat hypothalamus, septum and amygdala: a morphological and biochemical study. Endocrinology 1997;138: 778-789.

65 Eckersell CB, Popper P, Micevych PE: Estrogen-induced alteration of $\mu$-opioid receptor immunoreactivity in the medial preoptic nucleus and medial amygdala. J Neurosci 1998; 18:3967-3976.

66 Woolridge E, Barton S, Samuel J, Osorio J, Dougherty A, Holdcroft A: Cannabis use in HIV for pain and other medical symptoms. J Pain Symptom Manage 2005;29:358-367.

67 Haney M, Rabkin J, Gunderson E, Foltin RW: Dronabinol and marijuana in HIV+ marijuana smokers: acute effects on caloric intake and mood. Psychopharmacology (Berl) 2005;181:170-178.

68 Walsh D, Kirkova J, Davis MP: The efficacy and tolerability of long-term use of dronabinol in cancer-related anorexia: a case series. J Pain Symptom Manage 2005;30:493-495.

69 Lynch ME, Young J, Clark AJ: A case series of patients using medical marihuana for management of chronic pain under the $\mathrm{Ca}$ nadian Marihuana Medical Access Regulations. J Pain Symptom Manage 2006;32:497501.

70 Strasser F, Luftner D, Possinger K, Ernst G, Ruhstaller T, Meissner W, Ko YD, Schnelle M, Reif M, Cerny T: Comparison of orally administered cannabis extract and delta-9tetrahydrocannabinol in treating patients with cancer-related anorexia-cachexia syndrome: a multicenter, phase III, randomized, double-blind, placebo-controlled clinical trial from the cannabis-study-group. J Clin Oncol 2006;24:3394-3400. 